This item was submitted to Loughborough's Research Repository by the author.

Items in Figshare are protected by copyright, with all rights reserved, unless otherwise indicated.

\title{
Understanding the solution behavior of minor actinides in the presence of EDTA(4-), carbonate, and hydroxide ligands
}

PLEASE CITE THE PUBLISHED VERSION

http://dx.doi.org/10.1021/ic302260a

\section{PUBLISHER}

(C) American Chemical Society

VERSION

AM (Accepted Manuscript)

\section{PUBLISHER STATEMENT}

This work is made available according to the conditions of the Creative Commons Attribution-NonCommercialNoDerivatives 4.0 International (CC BY-NC-ND 4.0) licence. Full details of this licence are available at: https://creativecommons.org/licenses/by-nc-nd/4.0/

\section{LICENCE}

CC BY-NC-ND 4.0

\section{REPOSITORY RECORD}

Griffiths, Tamara L., Leigh R. Martin, Peter R. Zalupski, John Rawcliffe, Mark J. Sarsfield, Nicholas D.M. Evans, and Clint A. Sharrad. 2019. "Understanding the Solution Behavior of Minor Actinides in the Presence of EDTA(4-), Carbonate, and Hydroxide Ligands". figshare. https://hdl.handle.net/2134/15939. 


\section{Understanding the solution behaviour of minor}

\section{actinides in the presence of EDTA, carbonate and}

\section{hydroxide ligands}

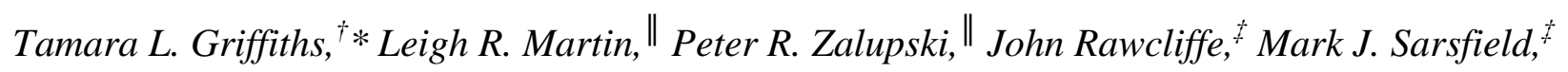
Nick D. M. Evans, ${ }^{\S}$ and Clint A. Sharrad ${ }^{\dagger \#} *$

${ }^{\dagger}$ Centre for Radiochemistry Research, School of Chemistry, The University of Manchester, Oxford Road, Manchester, M13 9PL, U.K.; "Aqueous Separations and Radiochemistry Department, Idaho National Laboratory, P.O. Box 1625, Idaho Falls, ID 83415-6150, USA.;

${ }^{\ddagger}$ National Nuclear Laboratory, Sellafield, Seascale, Cumbria, CA20 1PG, UK.; ${ }^{\S}$ Department of Chemistry, Loughborough University, Loughborough, Leicestershire, LE11 3TU, UK.; " School of Chemical Engineering and Analytical Science, The University of Manchester, Oxford Road, Manchester, M13 9PL, U.K.; ${ }^{\perp}$ Research Centre for Radwaste and Decommissioning, Dalton Nuclear Institute, The University of Manchester, Oxford Road, Manchester, M13 9PL, U.K.

Email: Clint.A.Sharrad@manchester.ac.uk 


\section{Abstract}

The aqueous solution behaviour of $\mathrm{An}^{\mathrm{III}}(\mathrm{An}=\mathrm{Am}$ or $\mathrm{Cm})$ in the presence of EDTA ${ }^{4-}$ (ethylenediamine tetraacetate), $\mathrm{CO}_{3}{ }^{2-}$ (carbonate) and $\mathrm{OH}^{-}$(hydroxide) ligands has been probed in aqueous nitrate solution (various concentrations) at room temperature by Ultra Violet-Visible (UV-Vis) and luminescence spectroscopies (Cm systems analysed using UV-Vis only). Ternary complexes have been shown to exist, including $\left[\mathrm{An}(\mathrm{EDTA})\left(\mathrm{CO}_{3}\right)\right]_{(\text {aq) }}^{3-}$, $\left(\right.$ where $\mathrm{An}=\mathrm{Am}^{\mathrm{III}}$ or $\mathrm{Cm}^{\mathrm{III}}$ ), which form over the $\mathrm{pH}$ range 8 to 11 . It is likely that carbonate anions and water molecules are in dynamic exchange for complexation at the remaining coordination sites. The carbonate ion is expected to bind as a bidentate ligand and replaces two coordinated water molecules in the $\left[\mathrm{An}(\mathrm{EDTA})\left(\mathrm{H}_{2} \mathrm{O}\right)_{3}\right]^{-}$complex.

In a 1:1 $\mathrm{Am}^{\mathrm{III}}$ :EDTA ${ }^{4-}$ binary system, luminescence spectroscopy shows that the number of coordinated water molecules $\left(N_{\mathrm{H}_{2} \mathrm{O}}\right)$ decreases from $\sim 8$ to $\sim 3$ as $\mathrm{pH}$ is increased from approximately 1 to 10 . This is likely to represent the formation of the $\left[\mathrm{Am}(\mathrm{EDTA})\left(\mathrm{H}_{2} \mathrm{O}\right)_{3}\right]^{-}$ species as $\mathrm{pH}$ is raised. For a $1: 1: 1 \mathrm{Am}^{\mathrm{III}}$ :EDTA ${ }^{4-}: \mathrm{CO}_{3}{ }^{2-}$ ternary system, the $N_{\mathrm{H}_{2} \mathrm{O}}$ to the [Am(EDTA)] $_{\text {(aq) }}$ species over the $\mathrm{pH}$ range 8 to 11 is $\sim 2$ to $\sim 3$ (cf. $\sim 3$ to $\sim 4$ in the binary system), indicating formation of the $\left[\mathrm{An}(\mathrm{EDTA})\left(\mathrm{CO}_{3}\right)\right]^{3-}$ (aq) species. As $\mathrm{pH}$ is further increased from approximately 10 to 12 in both systems, there is a sharp decrease from $\sim 3$ to $\sim 2$ in the binary system and from $\sim 2$ to $\sim 1$ in the ternary system. This is likely to correlate to the formation of hydrolysed species (e.g. [Am(EDTA)(OH) $]^{2-}{ }_{(\text {aq })}$ and/or $\left.\mathrm{Am}(\mathrm{OH})_{3(\mathrm{~s})}\right)$. 


\section{Introduction}

The complexation of actinide ions with aminocarboxylate ligands has received much interest over the years because of their relevance to nuclear waste streams. ${ }^{1-4}$ Trivalent actinides behave as hard cations, and predominantly participate in ionic bonding with ligands that contain hard donor groups. ${ }^{5}$ In the environment, polyaminocarboxylate donors can exist within humic substances, which are formed from the decomposition of organic matter. ${ }^{6}$ Almost all metal ions form thermodynamically stable complexes with humic substances, ${ }^{7}$ with reported $\log \beta$ values for $\mathrm{Am}^{\mathrm{III}}$ and $\mathrm{Cm}^{\mathrm{III}}$ complexation ranging from 6 to 17 at pHs from approximately 4 to $12^{8,9-11}$ The aminocarboxylate ligand, ethylenediamine tetraacetate (EDTA ${ }^{4-}$; Figure 1), may be used as a model for humic substances present in the environment. This is because EDTA ${ }^{4-}$ contains hard (4 oxygen) and, in comparison, relatively soft (2 nitrogen) donor groups, which are commonly found in humic substances. EDTA ${ }^{4-}$ provides a hexadentate ligand environment and forms complexes with relatively high thermodynamic stabilities with most metal ions including Am ${ }^{\text {III }}$ and $\mathrm{Cm}^{\mathrm{III}}\left(\log \beta_{[\mathrm{Am}(\mathrm{EDTA})]^{-}}=16.4\right.$ and $\log \beta_{[\mathrm{Cm}(\mathrm{EDTA})]^{-}}=16.7$, both determined in $0.5 \mathrm{M} \mathrm{Na}^{+}$ electrolyte at $\left.25{ }^{\circ} \mathrm{C}\right) .{ }^{12}$ Any remaining metal ion coordination sites in the EDTA complex are typically occupied by water molecules in aqueous solutions, or by other ligands that are present in solution. ${ }^{13}$ Secondary ligands are able to bind to $f$-ion complexes of EDTA $^{4-}$ by displacing some of the inner sphere water molecules and result in the formation of a ternary complex. This has been shown to occur for actinide and lanthanide complexes of EDTA ${ }^{4-}$ where the secondary ligand is nitrilotriacetate (NTA), iminodiacetate (IDA), oxydiacetate (ODA) and citrate (see Figure 1). ${ }^{13-16}$ However, few studies have observed the formation of ternary complexes of the actinides or lanthanides with carbonate. ${ }^{17}$ Actinide complexes of EDTA ${ }^{4-}$ can be soluble at both 
acidic and alkaline pHs, and may be used as a model to understand the migration and speciation of radionuclides in the environment, as well as the behaviour of actinides in various effluents and matrices. ${ }^{18}$ Carbonate is an environmentally important and ubiquitous ligand, being found in ground and surface waters at concentrations between $10^{-2} \mathrm{M}$ to $10^{-5} \mathrm{M} .^{19}$ The carbonate ion forms strong ionic interactions, due to its bidentate oxygen donors, with cations of the $f$ elements. ${ }^{19}$ These carbonate salts of the $4 f$ and $5 f$ trivalent ions are generally insoluble over neutral to alkaline $\mathrm{pH}$ values, with solubilities less than $10^{-8} \mathrm{M}^{20,21}$

We report our studies of the aqueous behaviour of Am ${ }^{\mathrm{III}}$-EDTA species in the presence and absence of carbonate ions using both UV-Vis and luminescence spectroscopies, whilst the analogous $\mathrm{Cm}^{\mathrm{III}}$ species have been investigated using UV-Vis spectroscopy.

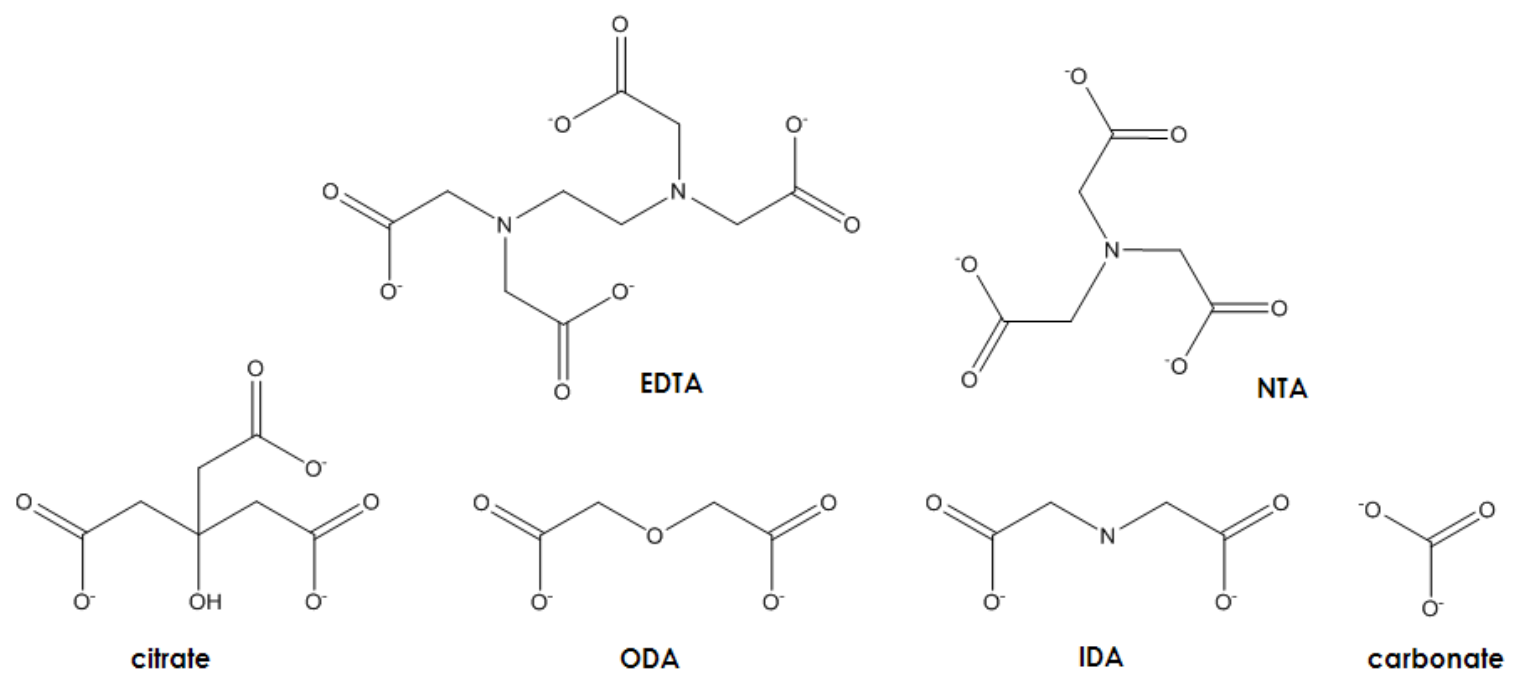

Figure 1. Structures of the EDTA, NTA, citrate, ODA, IDA and carbonate ligands. 


\section{Experimental Section}

\section{Radionuclide Warning}

${ }^{243} \mathrm{Am}$ and ${ }^{248} \mathrm{Cm}$ are radionuclides with high specific activities that should only be manipulated in a specifically designated facility in accordance with appropriate safety controls. All spectroscopic measurements were undertaken either in controlled facilities and/or using multiple containment procedures.

${ }^{243} \mathrm{Am}^{\mathrm{III}}$ and ${ }^{248} \mathrm{Cm}^{\mathrm{III}}$ studies were performed at Idaho National Laboratory (INL) and stock radionuclide solutions were obtained in nitric acid solution. The concentrations of Am and Cm in the stock solutions used at INL were determined by ICP-MS. The initial ionic strength of all working solutions at INL was $0.5 \mathrm{M} \mathrm{NaNO}_{3}$.

${ }^{243} \mathrm{Am}^{\mathrm{III}}$ luminescence studies were conducted at National Nuclear Laboratory (NNL), Sellafield, Cumbria and the Am ${ }^{\text {III }}$ stock solution was received in a hydrochloric medium. This Am ${ }^{\text {III }}$ in aqueous chloride solution was evaporated to dryness under a heat lamp, and then re-dissolved in an aqueous nitrate solution (2 M). Gamma spectroscopy was used to determine the ${ }^{243} \mathrm{Am}$ concentration in samples prepared at NNL.

All chemicals were reagent grade or higher. Milli-Q water (18 $\mathrm{M} \Omega$ ) was used in preparations of all solutions. Stock solutions of disodium EDTA (Aldrich) and sodium bicarbonate (Aldrich) were prepared by dissolution in water.

Ultraviolet-visible (UV-Vis) absorption spectra of solutions containing ${ }^{243} \mathrm{Am}^{\mathrm{III}}$ and ${ }^{248} \mathrm{Cm}^{\mathrm{III}}$ were recorded at INL using a Varian Cary-6000i spectrophotometer coupled with a Liquid Waveguide Capillary Cell (LWCC) equipped with a fibre optic interface. The cell had an internal 
volume of $2 \mathrm{~mL}$, a $1 \mathrm{~m}$ pathlength and an effective wavelength range of approximately 300$850 \mathrm{~nm}$. Spectra were recorded between $490-540 \mathrm{~nm}$ and 350-650 $\mathrm{nm}$ for $\mathrm{Am}^{\mathrm{III}}$ and $\mathrm{Cm}^{\mathrm{III}}$ containing solutions, respectively, at $0.1 \mathrm{~nm}$ intervals. The initial concentrations of the $[\mathrm{Am}(\mathrm{EDTA})]_{(\mathrm{aq})}^{-}$and $[\mathrm{Cm}(\mathrm{EDTA})]_{(\mathrm{aq})}^{-}$complexes were $5 \times 10^{-5} \mathrm{M}$ and $2 \times 10^{-5} \mathrm{M}$, respectively. In each titration, appropriate aliquots of the titrant $\left(\mathrm{NaOH}\right.$ or $\left.\mathrm{NaHCO}_{3}\right)$ were added into the cell and mixed thoroughly before each spectrum was collected. A set of 10-12 spectra were generated for each UV-Vis spectroscopic titration. The electromotive force (EMF, in millivolts) was measured with a Metrohm $\mathrm{pH}$ meter (Model 713) equipped with a Ross combination $\mathrm{pH}$ electrode (Orion Model 8102) after each titrant addition. The electrode filling solution was 5.0 M $\mathrm{NaCl}_{(\mathrm{aq})}$. The linear fit from the electrode calibration was used to calculate the $\mathrm{pH}$ from the EMF in the metal-ligand titrations.

Luminescence spectroscopic titrations of ${ }^{243} \mathrm{Am}^{\mathrm{III}}$ containing solutions were conducted at NNL. A Quantel Brilliant B Nd:YAG laser, which gave an output of $1064 \mathrm{~nm}$, was used to optically pump the tunable dye laser (Quantel TDL-90) after passing through a second harmonic generator (output $532 \mathrm{~nm}$ ) and third harmonic generator $(355 \mathrm{~nm}$ ). The dye laser was tuned to produce the desired excitation wavelength of $503 \mathrm{~nm}$ for $\mathrm{Am}^{\mathrm{III}}$. Fibre optics were used to focus the emitted light onto a Acton SpectraPro 2500i spectrograph combined with Princeton instruments, ST133 controller and Pi-Max Charged Coupled Device (CCD) camera (0.500 m Imaging Triple Grating Monochromator). Data were collected within a gate width of 70 to 120 ns, with a 5.55 ns delay width. The instrument was controlled remotely using Winspec software. Data were processed using Grams/AI software and analysed by linear regression on Microsoft Excel 2007. A daily mercury/argon (HgAr) wavelength calibration was performed before Am ${ }^{\text {III }}$ measurements were recorded. For maximum power output of the laser, the Coumarin 500 dye 
had to be changed weekly. The Am ${ }^{\text {III }}$ containing samples were introduced into the luminescence cuvette using a flow system. The initial concentration of the $[\text { Am(EDTA)] }]_{(\text {aq) }}^{-}$complex was $4 \times$ $10^{-4} \mathrm{M}$. A pH electrode (Cole Palmer Model PC1R2A), calibrated using pH 4, 7 and 11 buffers, was also fitted into the flow circuit to allow pH measurements to be taken. 


\section{Results and Discussion}

\section{UV-Vis Spectroscopy}

\section{$\mathrm{Am}^{\mathrm{III}} / \mathrm{Cm}^{\mathrm{III}}$-EDTA Binary Systems}

The complexation of $\mathrm{Am}^{\mathrm{III}}$ and $\mathrm{Cm}^{\mathrm{III}}$ with $\mathrm{EDTA}^{4-}$ as a function of $\mathrm{pH}$ has been studied by UVVis absorption spectroscopy (Figures 2 and 3, respectively). The absorption maximum $\left(\lambda_{\max }\right)$ of $\mathrm{Am}^{\mathrm{III}}$ in aqueous $0.5 \mathrm{M} \mathrm{NaNO}_{3}$ solution is found at $503 \mathrm{~nm}$, which corresponds to an electronic transition from the ${ }^{7} \mathrm{~F}_{0}$ ground state to the ${ }^{5} \mathrm{~L}_{6}$ excited state. ${ }^{11,22}$ On complexation with EDTA ${ }^{4-}$, there is a bathochromic shift of the $\lambda_{\max }$ for this transition to $507 \mathrm{~nm}$ accompanied by an increase in the apparent extinction coefficient $\left(\varepsilon^{*}\right)$. As the $\mathrm{pH}$ of this system is increased from 3 to 11 , a very small red-shift of the peak maximum occurs coupled with a broadening of the absorption profile. This may be due to the deprotonation of the bound ligand, thus causing a change in the average denticity of the EDTA ligand to the Am ${ }^{\text {III }}$ cation (i.e. conversion from $[\text { Am(EDTAH) }]_{(\mathrm{aq})}$ to $[\text { Am(EDTA) }]_{(a q)}^{-}$). This has been previously observed in La ${ }^{\text {III }}$-EDTA containing systems, where the $[\mathrm{La}(\mathrm{EDTAH})]_{(\mathrm{aq})}$ species is dominant from $\mathrm{pH} 2$ to 4 . As $\mathrm{pH}$ is increased further in this system, the $[\mathrm{La}(\mathrm{EDTAH})]_{(\mathrm{aq})}$ species deprotonates to form the $[\mathrm{La}(\mathrm{EDTA})]^{-}{ }_{(\mathrm{aq})}$ complex (Suppl. Info). ${ }^{12}$

At $\mathrm{pH}$ values greater than 11, the apparent extinction coefficient begins to decrease, which may be due to the formation of hydrolysed species (e.g. $[\mathrm{Am}(\mathrm{EDTA})(\mathrm{OH})]^{2-}{ }_{(\mathrm{aq})}$ and $\left.\mathrm{Am}(\mathrm{OH})_{3(\mathrm{~s})}\right)$. The precipitation of $\mathrm{Am}(\mathrm{OH})_{3(\mathrm{~s})}$ was not directly observed in the experiments, possibly because low metal ion concentrations were used (i.e. $\leq 5 \times 10^{-5} \mathrm{M}$ ). However, the precipitation of small amounts of $\mathrm{An}(\mathrm{OH})_{3(\mathrm{~s})}\left(\mathrm{An}=\mathrm{Am}^{\mathrm{III}}\right.$ or $\left.\mathrm{Cm}^{\mathrm{III}}\right)$ must be considered possible at high $\mathrm{pH}$ in all of the systems studied. In the 1:1 $\mathrm{An}^{\mathrm{III}}$ :EDTA ${ }^{4-}$ binary systems, $\mathrm{CO}_{2}$ was not excluded from the system. 
Precipitates such as $\mathrm{Am}\left(\mathrm{CO}_{3}\right)(\mathrm{OH})_{(\mathrm{s})}$ have been reported to form in $\mathrm{CO}_{2}$ saturated solutions and under varying partial pressures of $\mathrm{CO}_{2} ;{ }^{23}$ however, it is unlikely that this precipitate would form under the conditions used in our study.

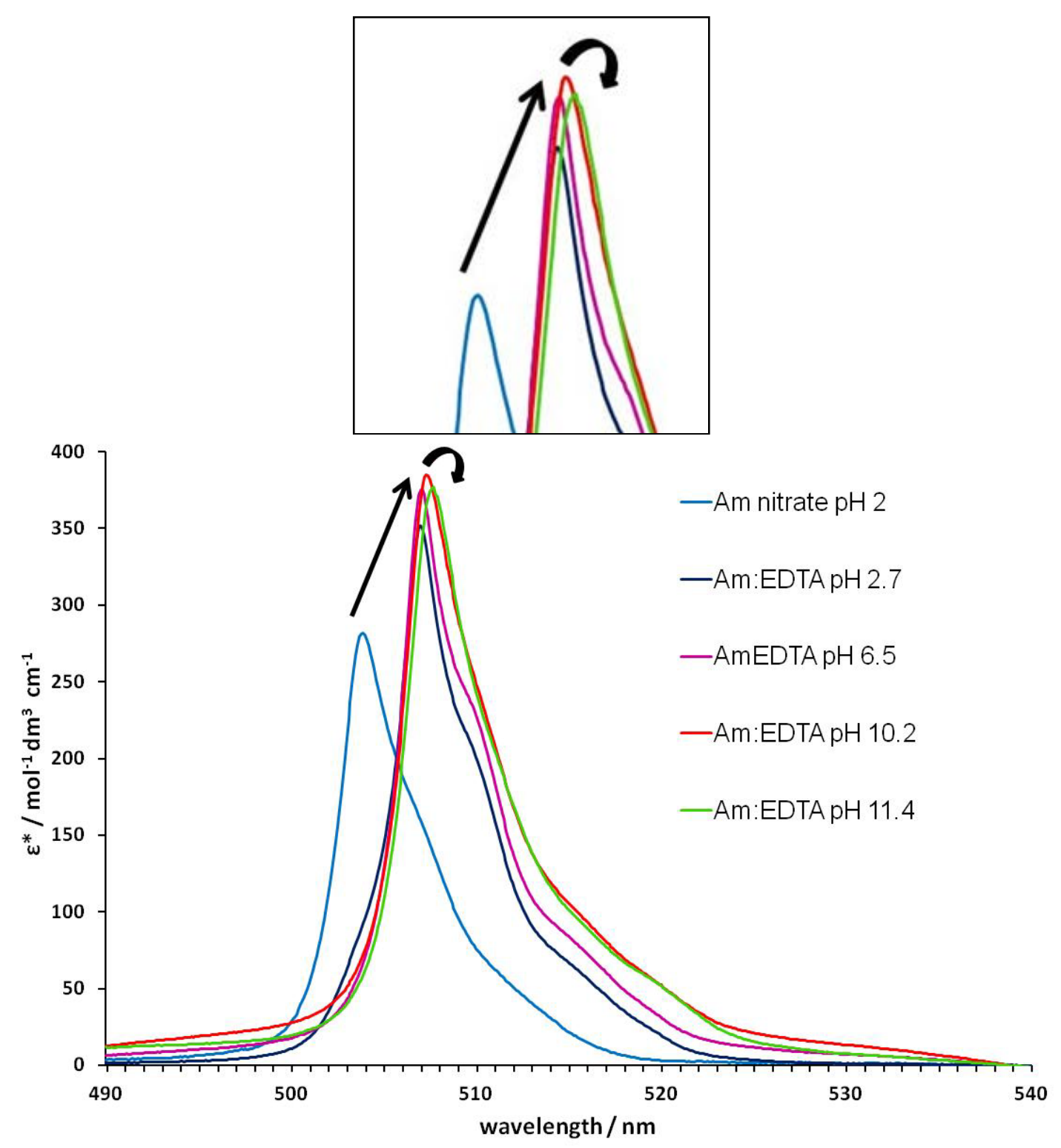

Figure 2. UV-Vis absorption spectra for the effect of pH on a 1:1 Am ${ }^{\mathrm{III}}$ :EDTA ${ }^{4-}$ system; $\left[\mathrm{Am}^{\mathrm{III}}\right]_{\mathrm{i}}=\left[\mathrm{EDTA}^{4-}\right]_{\mathrm{i}}=5 \times 10^{-5} \mathrm{M} ; I_{o}=0.5 \mathrm{M} \mathrm{NaNO}_{3}$. Inset: Zoom-in of absorption maxima. 
All of the measured $\mathrm{Cm}^{\mathrm{III}}$ spectra display sharp and relatively weak absorption bands, as expected for $f-f$ transitions, upon an intense, broad transition in the UV region of the spectrum (see Suppl. Info.). This broad absorption has been previously observed in the spectra of $\mathrm{Cm}^{\mathrm{III}}$ solutions, and has been attributed to radiolytic decomposition of water with time. ${ }^{24} \mathrm{All} \mathrm{Cm}^{\mathrm{III}}$ spectra presented have been adjusted by fitting and subtracting the broad transition in the UV region in order to distinguish between changes in the $\mathrm{Cm}^{\mathrm{III}}$ absorption profile and solvent decomposition. The $\mathrm{Cm}^{\mathrm{III}}$ spectra show absorption bands at 377, 382, 397, 434 and $456 \mathrm{~nm}$ (Figure 3), of which the most intense band at $397 \mathrm{~nm}$ corresponds to the electronic transition from the ${ }^{8} \mathrm{~S}_{7 / 2}$ ground state to the ${ }^{6} \mathrm{I}_{17 / 2}$ excited state. ${ }^{4,5}$ Raising the $\mathrm{pH}$ of the $1: 1 \mathrm{Cm}^{\mathrm{III}}$ :EDTA system from pH 4.2 to 10.8 causes a red-shift in all of the transitions, coupled with an increase in the apparent extinction coefficient, of the $\mathrm{Cm}^{\mathrm{III}}$ absorption profile. This is likely to represent an increase in the formation of the $[\mathrm{Cm}(\mathrm{EDTA})]_{(\mathrm{aq})}^{-}$complex. Above $\mathrm{pH} 10.8$, the observed decrease in the apparent extinction coefficients of the transitions in the $\mathrm{Cm}^{\mathrm{III}}$ spectra indicates a change in speciation which is likely to be due to the formation of $\mathrm{Cm}^{\mathrm{III}}$ containing hydrolysed species (e.g. $[\mathrm{Cm}(\mathrm{EDTA})(\mathrm{OH})]^{2-}{ }_{(\mathrm{aq})}$ or $\left.\mathrm{Cm}(\mathrm{OH})_{3(\mathrm{~s})}\right)$. 


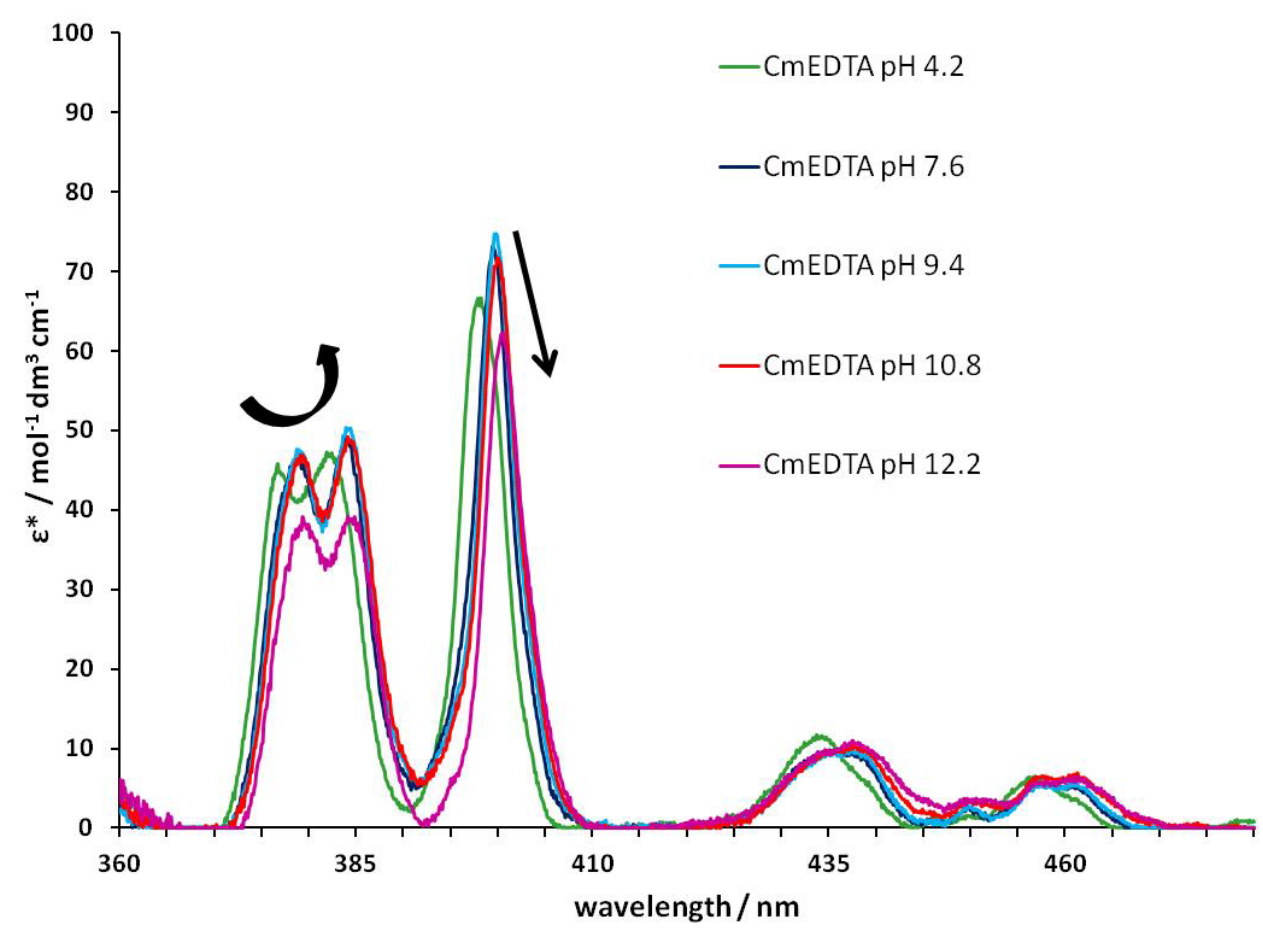

Figure 3. Adjusted UV-Vis absorption spectra for the effect of $\mathrm{pH}$ on a 1:1 $\mathrm{Cm}^{\mathrm{III}}$ :EDTA ${ }^{4-}$ system;

$$
\left[\mathrm{Cm}^{\mathrm{III}}\right]_{\mathrm{i}}=\left[\mathrm{EDTA}^{4-}\right]_{\mathrm{i}}=2 \times 10^{-5} \mathrm{M} ; I_{o}=0.5 \mathrm{M} \mathrm{NaNO}_{3} .
$$

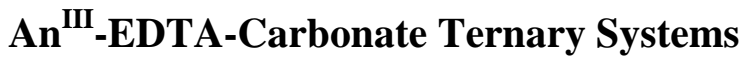

\section{An $=$ Am and $\mathbf{C m}$}

The UV-Vis absorption spectra of a 1:1 $\mathrm{An}^{\mathrm{III}}: \mathrm{EDTA}^{4-}$ system (where An $=\mathrm{Am}$ or Cm) have been measured as a function of carbonate ion concentration at $\mathrm{pH} 10 \pm 0.5$, adjusted using $\mathrm{NaOH}$ or $\mathrm{HNO}_{3}$ (Figures 4 and 5, respectively). The $\mathrm{pH}$ of the 1:1 $\mathrm{An}^{\mathrm{III}}$ :EDTA ${ }^{4-}$ systems were initially increased to approximately $\mathrm{pH} 10$, using $\mathrm{NaOH}$, before the addition of carbonate ions. As the carbonate ion concentration is increased in the $1: 1 \mathrm{An}^{\mathrm{III}}$ :EDTA ${ }^{4-}$ systems, there is a growth in the apparent extinction coefficient and a slight red shift of the absorption maxima. This growth in the apparent extinction coefficient, coupled with no evidence for the precipitation of $\mathrm{An}_{2}\left(\mathrm{CO}_{3}\right)_{3}$ (likely solubility-controlling precipitate) ${ }^{23}$ in the presence of EDTA ${ }^{4-}$, indicates the formation of 
the $\left[\mathrm{An}(\mathrm{EDTA})\left(\mathrm{CO}_{3}\right)\right]^{3-}{ }_{(\mathrm{aq})}$ species. The apparent extinction coefficient in the $1: 1: X$ $\mathrm{An}^{\mathrm{III}}: \mathrm{EDTA}^{4-}: \mathrm{CO}_{3}{ }^{2-}$ system (where $X=0$ to 2) continues to increase up to two equivalents of carbonate ions. This is likely to reflect the position of the equilibrium being favoured towards the formation of the $\left[\mathrm{An}(\mathrm{EDTA})\left(\mathrm{CO}_{3}\right)\right]^{3-}{ }_{\text {(aq) }}$ species. It is unlikely that the $\left[\mathrm{An}(\mathrm{EDTA})\left(\mathrm{CO}_{3}\right)_{2}\right]^{5-}{ }_{(\mathrm{aq})}$ species is formed, which is discussed below (see luminescence spectroscopy section on the Am ${ }^{\mathrm{III}}$-EDTA-carbonate ternary system).

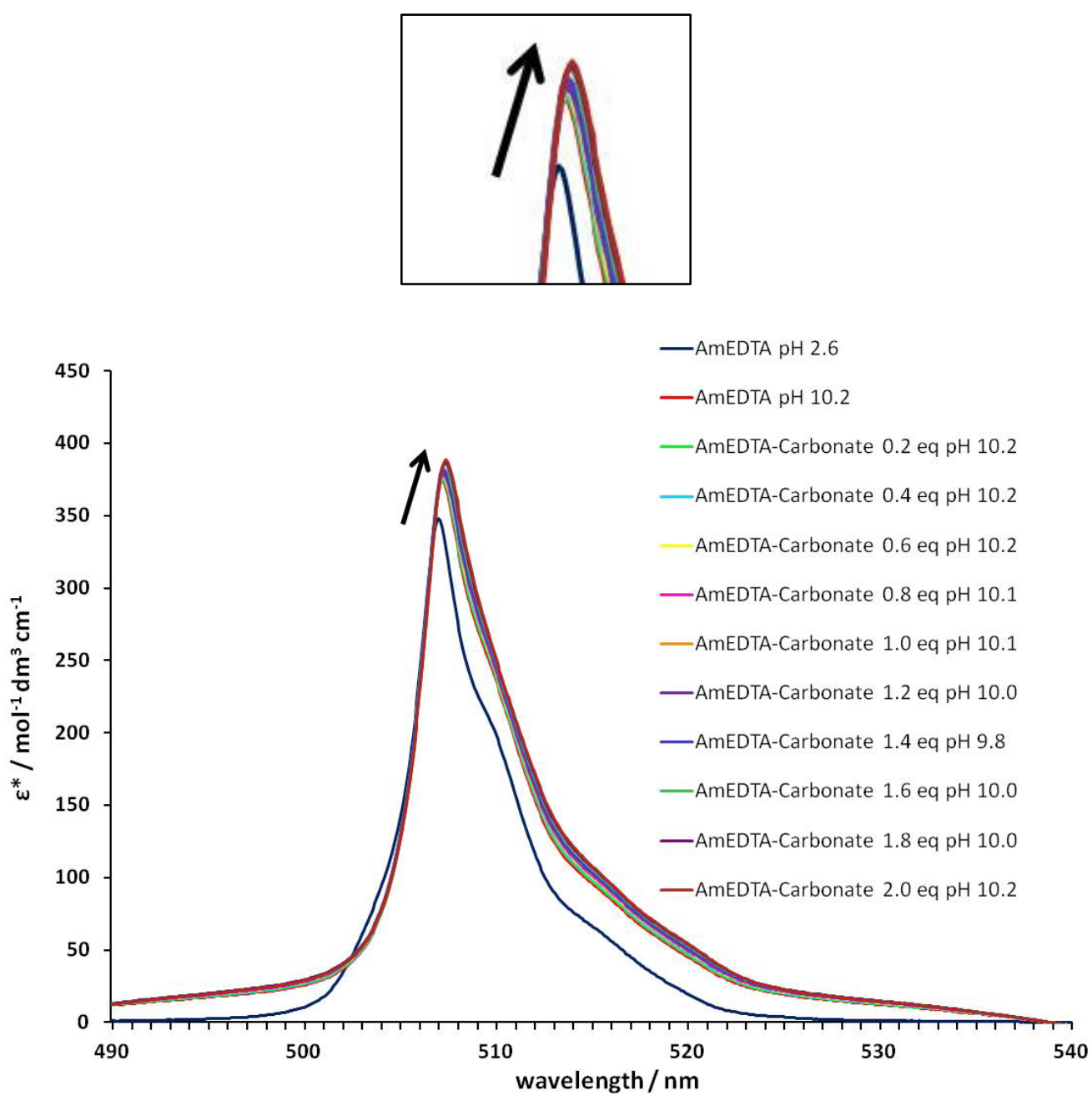

Figure 4. UV-Vis absorption spectra for a $1: 1: X \mathrm{Am}^{\mathrm{III}}: \mathrm{EDTA}^{4-}: \mathrm{CO}_{3}{ }^{2-}$ system (where $X=0$ to 2 equivalents); $\left[\mathrm{Am}^{\mathrm{III}}\right]_{\mathrm{i}}=\left[\mathrm{EDTA}^{4-}\right]_{\mathrm{i}}=\left[\mathrm{CO}_{3}{ }^{2-}\right]_{\mathrm{i}}=5 \times 10^{-5} \mathrm{M} ; \mathrm{pH}=10 \pm 0.5 ; I_{o}=0.5 \mathrm{M} \mathrm{NaNO}_{3}$. Inset: Zoom-in of absorption maxima. 


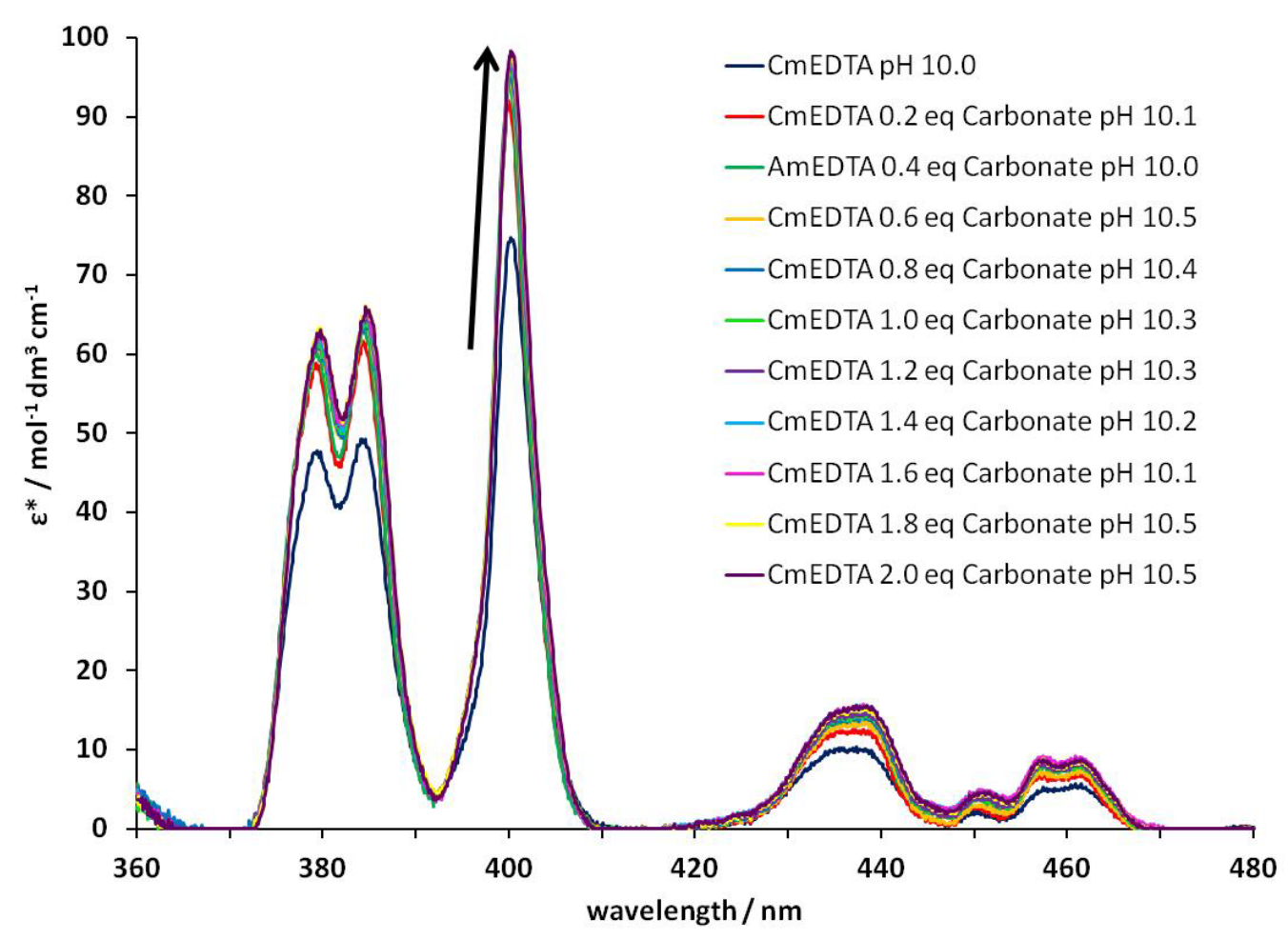

Figure 5. Adjusted UV-Vis absorption spectra for a 1:1:X $\mathrm{Cm}^{\mathrm{III}}: \mathrm{EDTA}^{4-}: \mathrm{CO}_{3}{ }^{2-}$ system (where $X=0$ to 2 equivalents); $\left[\mathrm{Cm}^{\mathrm{III}}\right]_{\mathrm{i}}=\left[\mathrm{EDTA}^{4-}\right]_{\mathrm{i}}=\left[\mathrm{CO}_{3}{ }^{2-}\right]_{\mathrm{i}}=2 \times 10^{-5} \mathrm{M} ; \mathrm{pH}=10 \pm 0.5 ; I_{o}=0.5 \mathrm{M} \mathrm{NaNO}_{3}$.

The effects of $\mathrm{pH}$, adjusted using $\mathrm{NaOH}$, on the absorption spectra of the 1:1:2 $\mathrm{Am}^{\mathrm{III}}: \mathrm{EDTA}^{4-}: \mathrm{CO}_{3}{ }^{2-}$ system are shown in Figure 6. As $\mathrm{pH}$ is increased from 10 to 12 , the apparent extinction coefficient decreases, and a slight red-shift of the peak maximum occurs after $\mathrm{pH}$ 11. It may be possible that these observations are due to the carbonate anion being replaced by the hydroxide ion/s above $\mathrm{pH} 11$. It has been reported that hydrolysed minor actinide species are likely to dominate over minor actinide carbonate complexes at $\mathrm{pH}$ values near $11 .^{23}$ 

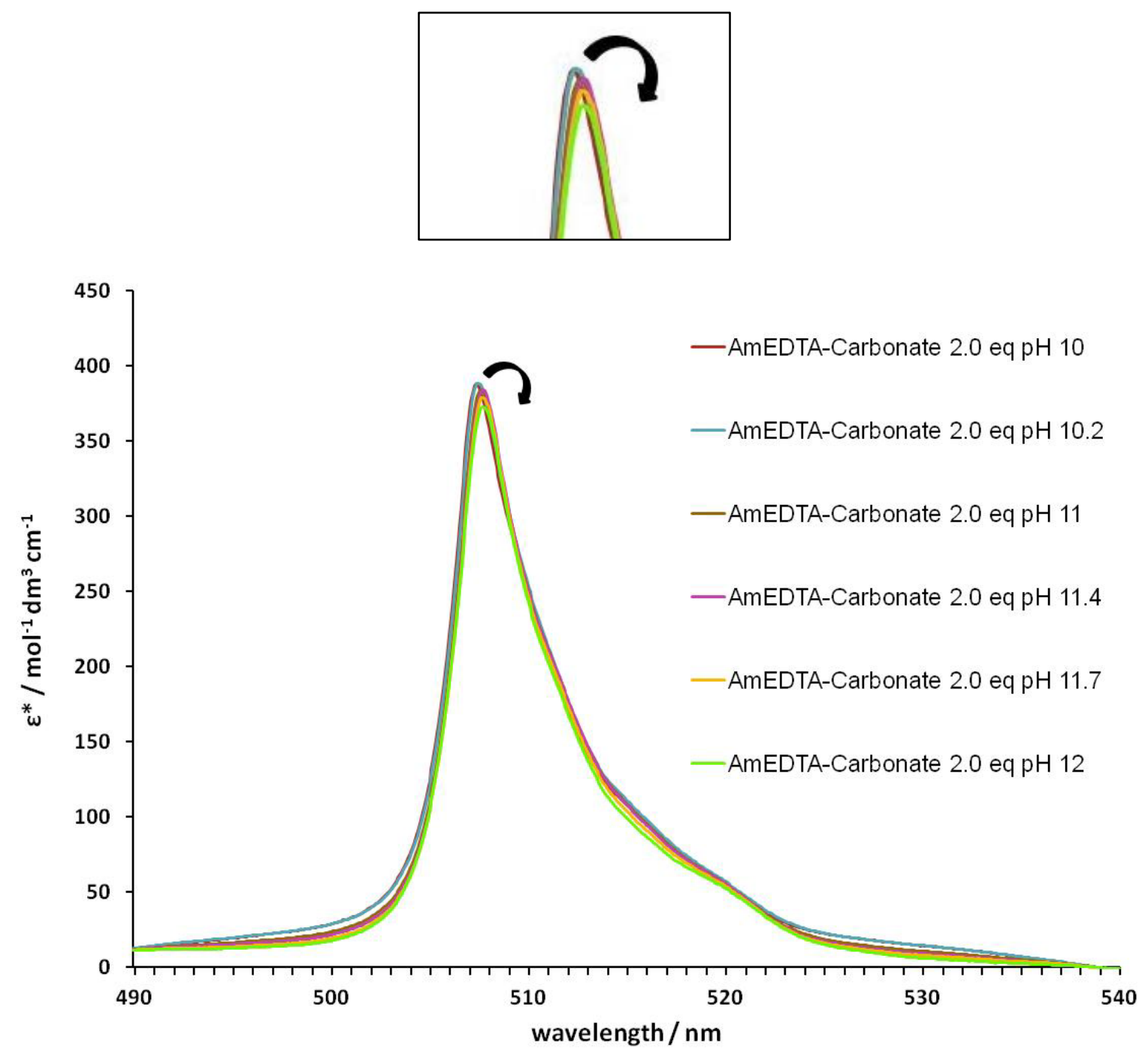

Figure 6. UV-Vis absorption spectra for the effect of $\mathrm{pH}$ on a 1:1:2 $\mathrm{Am}^{\mathrm{III}}: \mathrm{EDTA}^{4--}: \mathrm{CO}_{3}{ }^{2-}$ system; $\left[\mathrm{Am}^{\mathrm{III}}\right]_{\mathrm{i}}=\left[\mathrm{EDTA}^{4-}\right]_{\mathrm{i}}=5 \times 10^{-5} \mathrm{M} ;\left[\mathrm{CO}_{3}{ }^{2-}\right]_{\mathrm{i}}=1 \times 10^{-4} \mathrm{M} ; I_{o}=0.5 \mathrm{M} \mathrm{NaNO}_{3}$. Inset: Zoom-in of absorption maxima.

Time Resolved Laser Induced Fluorescence Spectroscopy of ${ }^{243} \mathrm{Am}^{\mathrm{III}}$

Time-resolved laser induced fluorescence spectroscopy (TRLIFS) can be used to study Am ${ }^{\text {III }}$ complexation with organic ligands in aqueous solution by determining the number of coordinated water molecules in the first coordination shell of the $\mathrm{Am}^{\mathrm{III}}$ ion. ${ }^{25}$ The time-resolved 
emission spectra of the $\mathrm{Am}^{\mathrm{III}}{ }_{\text {(aq) }}$ ion, upon excitation at $503 \mathrm{~nm}$, show emissions at approximately 691 and $833 \mathrm{~nm}$ (Figure 7), which are due to the ${ }^{5} \mathrm{D}_{1} \rightarrow{ }^{7} \mathrm{~F}_{1}$ and the ${ }^{5} \mathrm{D}_{1} \rightarrow{ }^{7} \mathrm{~F}_{2}$ transitions, respectively. ${ }^{26}$ Typically the emission band at $691 \mathrm{~nm}$ is used to probe $\mathrm{Am}{ }^{\mathrm{III}}$ complexation behaviour due to the relatively high emission intensity, ${ }^{11,25-27}$ therefore, only this band has been analysed in the work presented here. A plot of the intensity of the signal at $\lambda_{\max } v s$. the gate delay (see Suppl. Info.) illustrates the exponential decay of the signal after each 10 ns delay. A plot of $\ln ($ intensity) vs. the gate delay (see Suppl. Info.) gives a linear fit, from which the luminescent lifetime $(\tau)$ can be calculated using equation 1.

$$
\tau=-\frac{1}{m}
$$

where: $\quad \tau=$ luminescent lifetime (ns); $m=$ gradient.

The luminescence lifetime of the $\mathrm{Am}^{\mathrm{III}}{ }_{\text {(aq) }}$ ion in $0.02 \mathrm{M} \mathrm{HNO}_{3}$ aqueous solution was calculated to be $24.1 \pm 1.2 \mathrm{~ns}$ at room temperature (RT). This is in good agreement with previously reported luminescence lifetimes of $\mathrm{Am}^{\mathrm{III}}$ (aq), which range from 22 to $25 \mathrm{~ns}$ at 22 to $25^{\circ} \mathrm{C}$ in 0.01 to $0.10 \mathrm{M}$ $\mathrm{HClO}_{4}$ solution (pH not specified). ${ }^{11,26,27}$ 


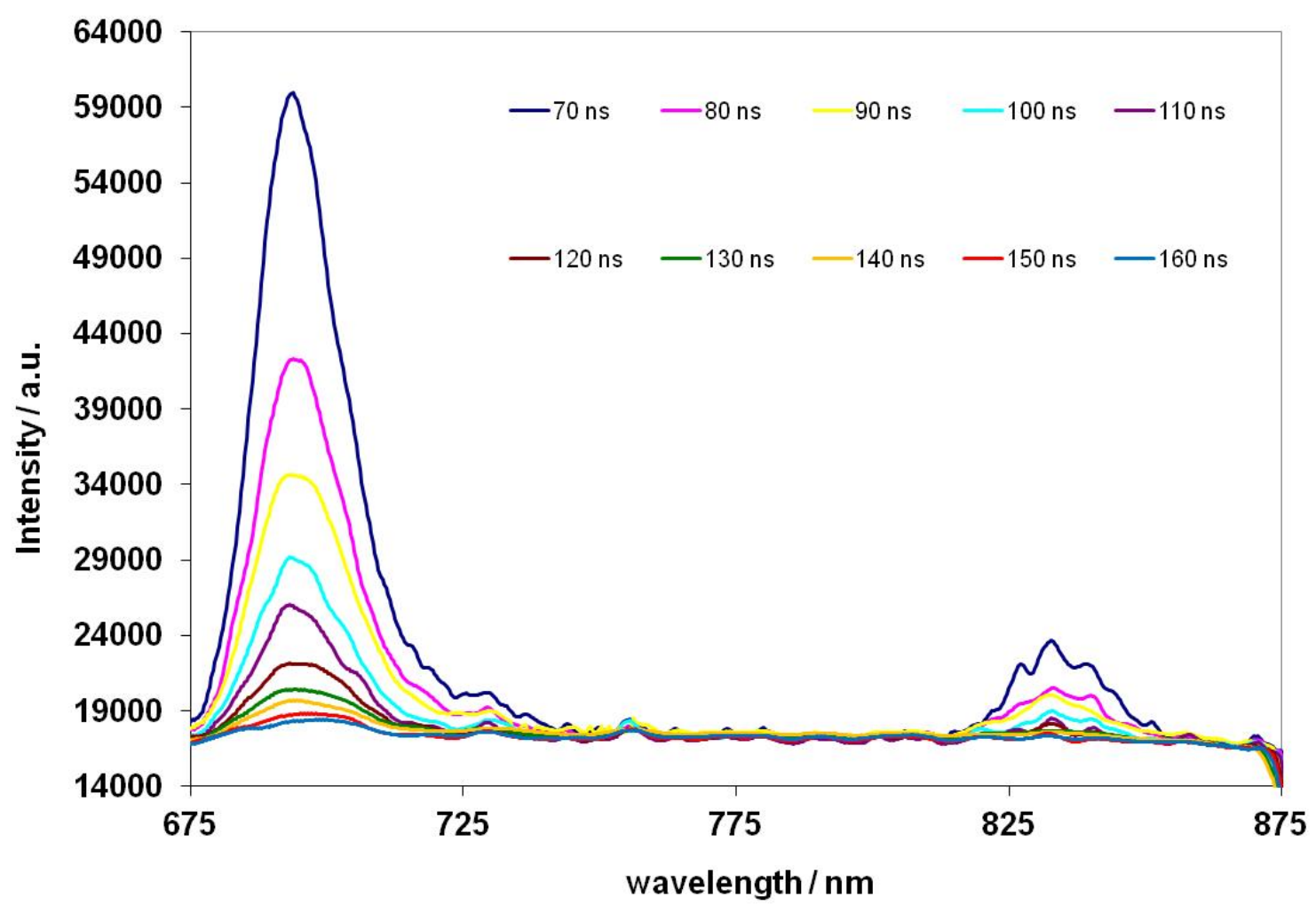

Figure 7. The time-resolved emission spectra of the $\mathrm{Am}_{\text {(aq) }}^{\mathrm{III}}$ ion; $\left[\mathrm{Am}^{\mathrm{III}}\right]=4 \times 10^{-4} \mathrm{M} ; \mathrm{I}=0.02 \mathrm{M} \mathrm{HNO}_{3}$.

The luminescence lifetimes can subsequently be used to determine the inner-sphere hydration number of the metal ion $\left(N_{\mathrm{H}_{2} \mathrm{O}}\right)$, thereby providing information on the metal ion coordination environment in solution. ${ }^{11}$ We have used the equation derived by Kimura et al. ${ }^{28}$ to calculate the $N_{\mathrm{H}_{2} \mathrm{O}}$ coordinated to the $\mathrm{Am}{ }^{\mathrm{III}}$ ion in various solution conditions from the luminescence lifetimes (equation 2).

$$
N_{\mathrm{H}_{2} \mathrm{O}}=\left(\frac{2.56 \times 10^{-7}}{\tau}\right)-1.43
$$

$(\text { Equation } 2)^{28}$ 
The value of the $N_{\mathrm{H}_{2} \mathrm{O}}$ coordinated to the $\mathrm{Am}^{\mathrm{III}}$ (aq) ion in $0.02 \mathrm{M} \mathrm{HNO}_{3}$ is calculated to be approximately nine. There are reports that detail nine inner-sphere water molecules associated with the $\mathrm{Am}^{\mathrm{III}}{ }_{\text {(aq) }}$ ion in aqueous solutions (pH not specified), characterised using absorption and

luminescence spectroscopies, and ten water molecules coordinated to the $\mathrm{Am}^{\mathrm{III}}$ (aq) ion in dilute aqueous chloride solutions ( $\mathrm{pH}$ not specified) determined by X-ray Absorption Fine Structure (XAFS) spectroscopy. ${ }^{29}$ The structure of the $\left[\mathrm{Am}\left(\mathrm{H}_{2} \mathrm{O}\right)_{9}\right]^{3+}$ species (crystals grown from trifluoromethanesulfonate media; $\mathrm{pH}$ not specified) has been reported previously, where the Am ${ }^{\text {III }}$ ion coordinates in a tri-capped, trigonal prismatic geometry. ${ }^{29,30}$ In accordance with the luminescence and absorption spectroscopies performed on aqueous solutions of the Am ${ }^{\mathrm{III}}$ ion, as well as the reported structure of the $\left[\mathrm{Am}\left(\mathrm{H}_{2} \mathrm{O}\right)_{9}\right]^{3+}$ species, it is assumed that the $\mathrm{Am}^{\text {III }}$ (aq) coordination number will be nine for the purposes of this work.

\section{Am ${ }^{\text {III }}$-EDTA Binary System}

The 1:1 Am ${ }^{\mathrm{III}}: \mathrm{EDTA}^{4-}$ system in aqueous nitrate solution $(2 \mathrm{M})$ has been examined using luminescence spectroscopy. The initial value of the $N_{\mathrm{H}_{2} \mathrm{O}}$ coordinated to the $\mathrm{Am}^{\mathrm{III}}$ (aq) ion at $\mathrm{pH}$ 0.5 in $2 \mathrm{M}$ aqueous nitrate solution is calculated to be 7.6 (no $\mathrm{EDTA}^{4-}{ }_{\text {(aq) }}$ present), which may correspond to some formation of the $\left[\mathrm{Am}\left(\mathrm{NO}_{3}\right)\left(\mathrm{H}_{2} \mathrm{O}\right)_{7}\right]^{2+}$ species in concentrated aqueous nitrate solutions (as shown in the speciation diagram; see Suppl. Info). On addition of $\operatorname{EDTA}_{(\text {aq) }}^{4-}$ to this solution, this causes the luminescence lifetime to increase and it continues to do so as $\mathrm{pH}$ is raised from approximately pH 1 to 12 (see Suppl. Info.). Subsequently, the $N_{\mathrm{H}_{2} \mathrm{O}}$ bound to the $\mathrm{Am}^{\mathrm{III}}$ ion in this system decreases (Figure 8). This indicates that as $\mathrm{pH}$ is increased, the equilibrium between the free $\mathrm{Am}_{(\mathrm{aq})}^{\mathrm{III}}$ ion/the $\left[\mathrm{Am}\left(\mathrm{NO}_{3}\right)\right]^{2+}{ }_{\text {(aq) }}$ complex and the EDTA ${ }^{4-}$ ligand with the $[\mathrm{Am}(\mathrm{EDTA})]^{-}$(aq) complex is favoured towards complex formation, as expected. This 
reduction in $N_{\mathrm{H}_{2} \mathrm{O}}$ bound to the $\mathrm{Am}{ }^{\mathrm{III}}$ ion causes the luminescence lifetime to increase as there are fewer $\mathrm{OH}$ oscillators to quench the $\mathrm{Am}{ }^{\text {III }}$ excited state. ${ }^{24}$ At $\mathrm{pH} 10.5$, the $N_{\mathrm{H}_{2} \mathrm{O}}$ bound to the Am ${ }^{\text {III }}$ ion is calculated to be approximately three, which can be represented by the [Am(EDTA)( $\left.\left.\mathrm{H}_{2} \mathrm{O}\right)_{3}\right]^{-}$species. At pH 12, the $N_{\mathrm{H}_{2} \mathrm{O}}$ bound to the [Am(EDTA)] ${ }_{\text {(aq) }}^{-}$species reduces to 1.8 , and so hydrolysed species are likely to be formed (i.e. $[\mathrm{Am}(\mathrm{EDTA})(\mathrm{OH})]^{2-}{ }_{(\mathrm{aq})}$ and $\left.\mathrm{Am}(\mathrm{OH})_{3(\mathrm{~s})}\right)$.

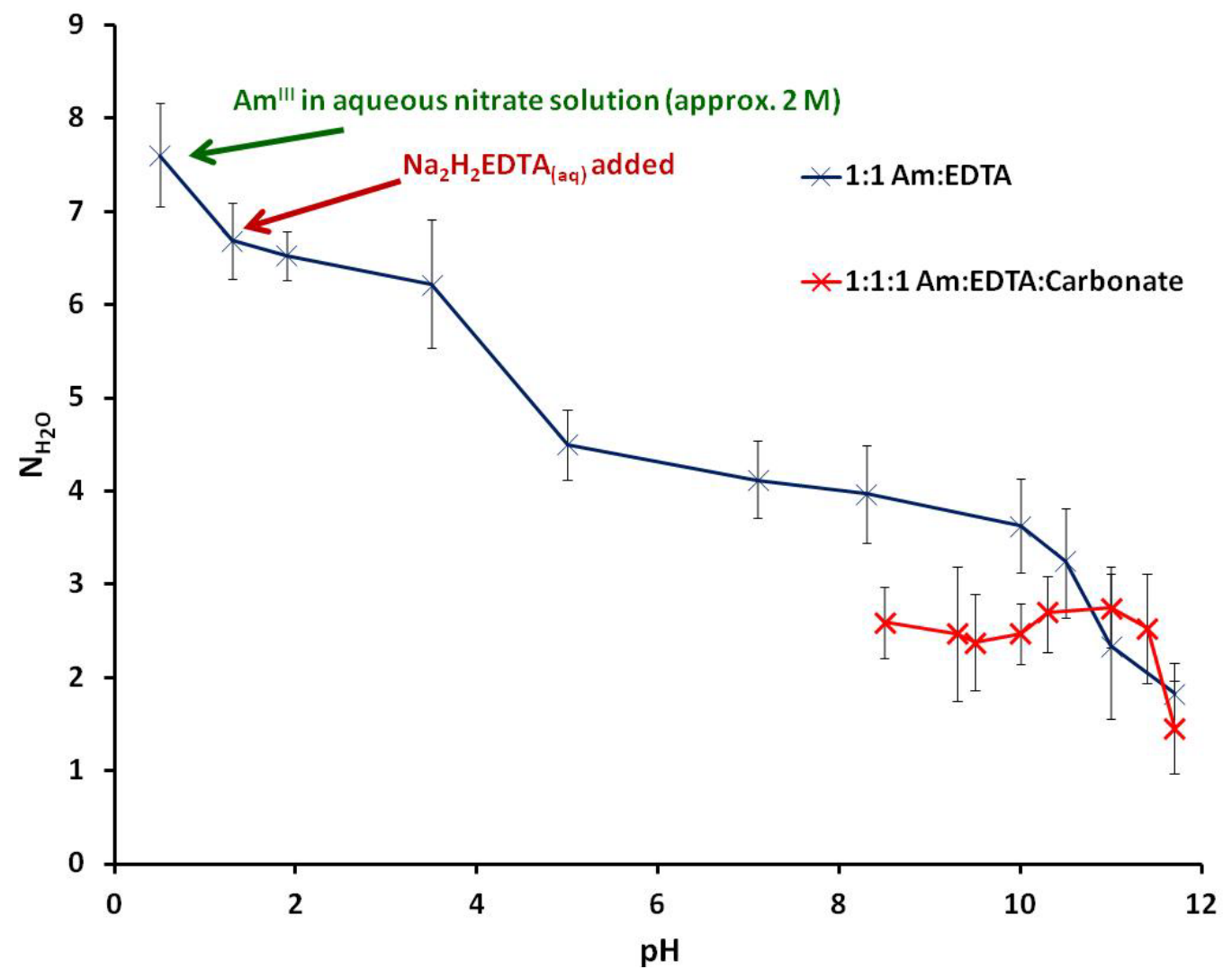

Figure 8. The effect of $\mathrm{pH}$ on the $N_{\mathrm{H}_{2} \mathrm{O}}$ bound to the Am ${ }^{\mathrm{III}}$ ion in the $1: 1 \mathrm{Am}^{\mathrm{III}}: \mathrm{EDTA}^{4-}\left(\left[\mathrm{Am}^{\mathrm{III}}\right]_{\mathrm{i}}=\left[\mathrm{EDTA}^{4-}\right]_{\mathrm{i}}=\right.$ $4 \times 10^{-4} \mathrm{M}$; in approx. $2 \mathrm{M}$ nitrate solution) and $1: 1: 1 \mathrm{Am}^{\mathrm{III}}: \mathrm{EDTA}^{4-}: \mathrm{CO}_{3}{ }^{2-}$ systems $\left(\left[\mathrm{Am}^{\mathrm{III}}\right]_{\mathrm{i}}=\left[\mathrm{EDTA}^{4-}\right]_{\mathrm{i}}=\left[\mathrm{CO}_{3}{ }^{2-}\right]_{\mathrm{i}}=\right.$ $4 \times 10^{-4} \mathrm{M}$; in approx. $2 \mathrm{M}$ nitrate solution). Average percentage error bars have been included for all plots of

$$
N_{\mathrm{H}_{2} \mathrm{O}} \text { Vs. pH. }
$$


Taking the assumption that the only species present in solution between $\mathrm{pH} 1$ to 10 are $\left[\mathrm{Am}\left(\mathrm{H}_{2} \mathrm{O}\right)_{9}\right]^{3+} /\left[\mathrm{Am}\left(\mathrm{NO}_{3}\right)\left(\mathrm{H}_{2} \mathrm{O}\right)_{7}\right]^{2+}$ and $\left[\mathrm{Am}(\mathrm{EDTA})\left(\mathrm{H}_{2} \mathrm{O}\right)_{3}\right]^{-}$, the $N_{\mathrm{H}_{2} \mathrm{O}}$ determined by luminescence can be used to assess the speciation of $\mathrm{Am}^{\mathrm{III}}$ ion in the presence of EDTA ${ }^{4-}$ (and its protonated analogues) with respect to $\mathrm{pH}$ (Figure 9). This speciation diagram shows that the percentage formation of the $[\mathrm{Am}(\mathrm{EDTA})]_{(\mathrm{aq})}^{-}$complex increases from approximately $24 \%$ to $85 \%$ over the $\mathrm{pH}$ range 3.5 to 10.0 .

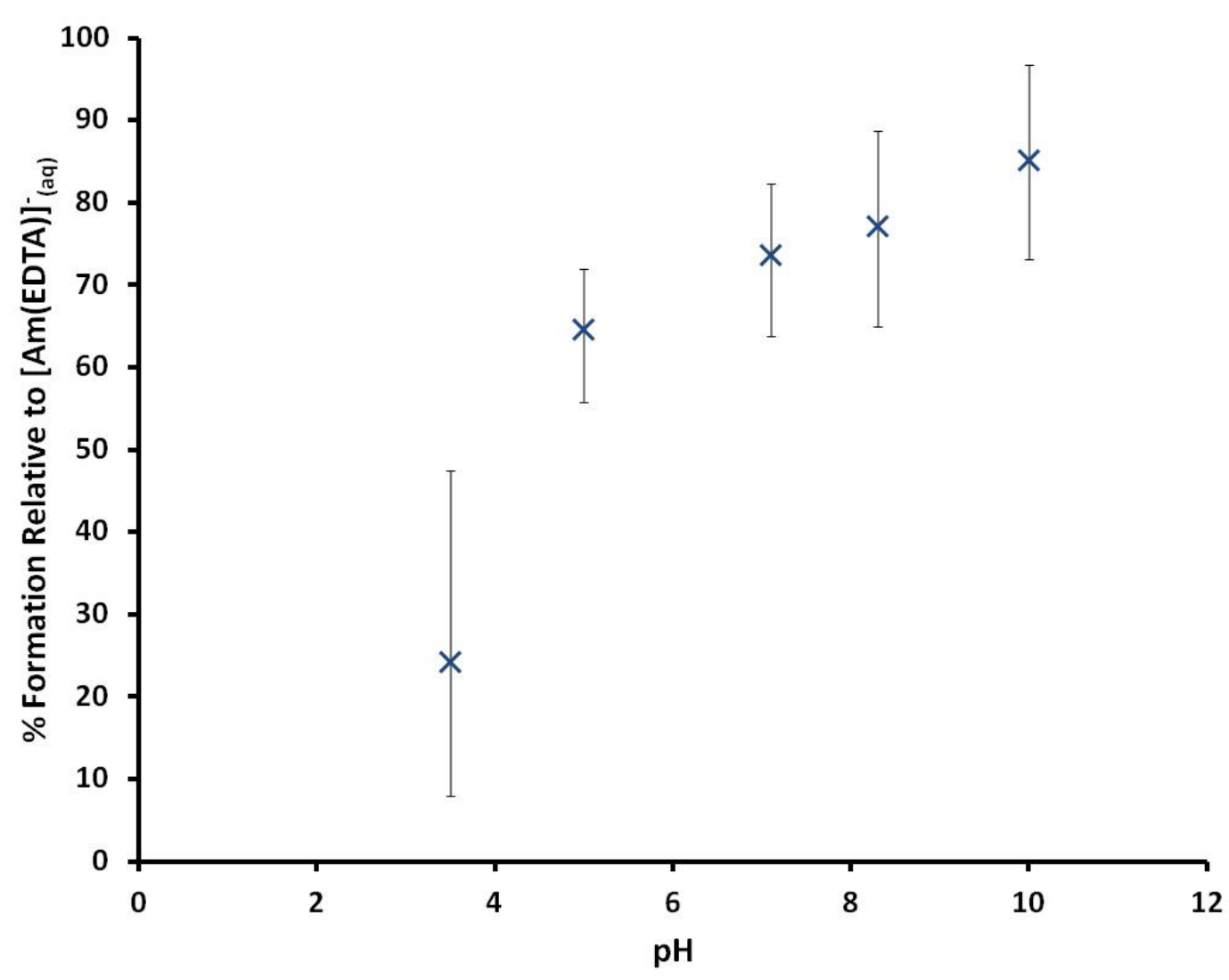

Figure 9. Plot of the percentage formation of the $\left[\mathrm{Am}(\mathrm{EDTA})\left(\mathrm{H}_{2} \mathrm{O}\right)_{3}\right]_{(\mathrm{aq})}^{-}$species as a function of $\mathrm{pH}$.

The stability constants for $[\mathrm{Am}(\mathrm{EDTA})]_{(\mathrm{aq})}^{-}\left(\log \beta_{[\mathrm{Am}(\mathrm{EDTA})]^{-}}=16.4\right.$ in $0.5 \mathrm{M} \mathrm{Na}^{+}$electrolyte at $\left.25{ }^{\circ} \mathrm{C}\right),\left[\mathrm{Am}\left(\mathrm{NO}_{3}\right)\right]^{2+}$ (aq) $\left(\log \beta_{\left[\mathrm{Am}\left(\mathrm{NO}_{3}\right)\right]^{2+}}=0.2\right.$ in $2 \mathrm{M} \mathrm{NH}_{4} \mathrm{ClO}_{4}$ electrolyte at $\left.25{ }^{\circ} \mathrm{C}\right)$ and 
$\mathrm{Am}(\mathrm{OH})_{3(\mathrm{~s})}\left(\log \beta_{[\mathrm{Am}(\mathrm{OH})]^{2+}}=6.4\right.$ in $0.7 \mathrm{M} \mathrm{NaCl}$ electrolyte at $\left.20{ }^{\circ} \mathrm{C}\right)$ have been previously determined using potentiometry. ${ }^{12}$ The speciation diagram for the $1: 1 \mathrm{Am}^{\mathrm{III}}$ :EDTA ${ }^{4-}$ system, derived from these known equilibrium constants is displayed in Figure $10 .^{12}$ This shows that from $\mathrm{pH} 0$ to 2, the $\left[\mathrm{Am}\left(\mathrm{NO}_{3}\right)\right]^{2+}{ }_{\text {(aq) }}$ species dominates the speciation of the $\mathrm{Am}^{\mathrm{III}}$ ion, whilst from $\mathrm{pH} 2$ to 11, the [Am(EDTA)] ${ }_{(\mathrm{aq})}$ species is dominant. Hydrolysis of the Am ${ }^{\mathrm{III}}$ ion to form $[\mathrm{Am}(\mathrm{EDTA})(\mathrm{OH})]^{2-}{ }_{(\mathrm{aq})}$ and $\mathrm{Am}(\mathrm{OH})_{3(\mathrm{~s})}$ is expected to dominate at $\mathrm{pH}$ greater than 11.

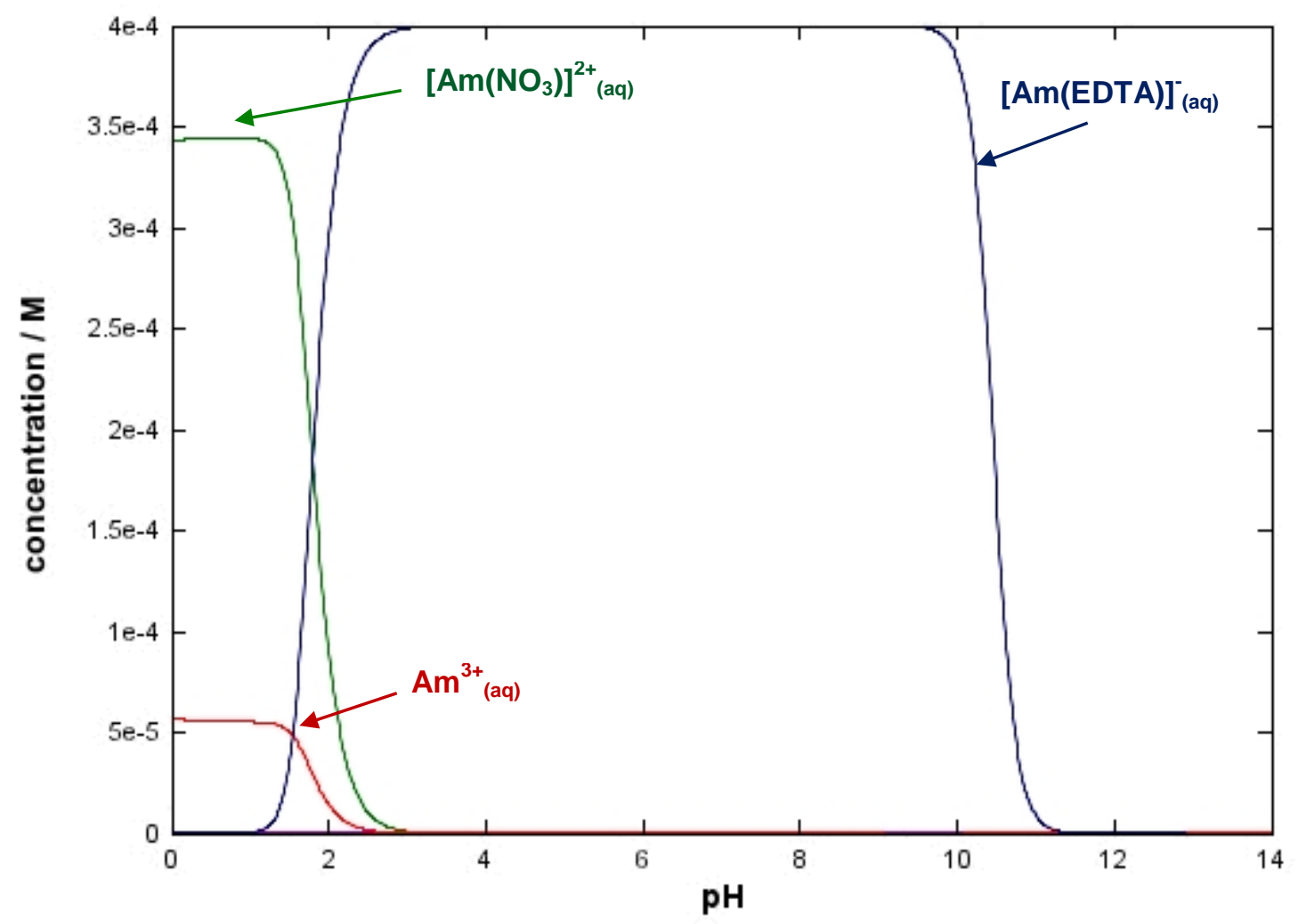

Figure 10. Speciation diagram of a $1: 1 \mathrm{Am}^{\mathrm{III}}: \mathrm{EDTA}^{4-}$ system as a function of $\mathrm{pH}$ using the JCHESS code. ${ }^{31}$ Total $\left[\mathrm{Am}^{\mathrm{III}}\right]=$ total $\left[\mathrm{EDTA}^{4-}\right]=4 \times 10^{-4} \mathrm{M} ;\left[\mathrm{NO}_{3}\right]^{-}=2 \mathrm{M}$. Only soluble species are shown. Thermodynamic data obtained from the integrated JCHESS database, as well as Martell and Smith (corrected to zero ionic strength using the Davies Equation). ${ }^{12}$ 
Differences in the speciation diagrams presented in Figures 9 and 10 suggest that other equilibria may be present at both acidic and alkaline $\mathrm{pH}$. For example, in the acidic $\mathrm{pH}$ region, there may be an equilibrium between the $[\mathrm{Am}(\mathrm{EDTAH})]_{(\mathrm{aq})}$ and $[\mathrm{Am}(\mathrm{EDTA})]_{(\mathrm{aq})}^{-}$species (i.e. pentadentate vs. hexadentate EDTA $^{4-}$ coordination). Similarly, at alkaline $\mathrm{pH}$, the $[\mathrm{Am}(\mathrm{EDTA})]^{-}{ }_{\text {(aq) }}$ complex may be in equilibrium with the hydrolysed species, $[\mathrm{Am}(\mathrm{EDTA})(\mathrm{OH})]_{(\mathrm{aq})}^{2-}$. Therefore, as the formation constants of the $[\operatorname{Am}(\operatorname{HEDTA})]_{(\mathrm{aq})}$ and $[\mathrm{Am}(\mathrm{EDTA})(\mathrm{OH})]^{2-}{ }_{(\mathrm{aq})}$ species are unknown, discrepancies in the calculated speciation diagram (Figure 10) may occur.

Possible structures of these solution species, which cause the discrepancies between the speciation diagrams derived from potentiometry and luminescence spectroscopy for the 1:1 $\mathrm{Am}^{\mathrm{III}}: \mathrm{EDTA}^{4-}$ system, are proposed in Figure 11. Although the equilibria between these species are likely to occur in the $\mathrm{pH}$ range studied, the formation of these species will not cause the gradual change of $N_{\mathrm{H}_{2} \mathrm{O}}$ from $\sim 8$ to $\sim 3 / 4$ over $\mathrm{pH} 1$ to 10 observed by luminescence spectroscopy.

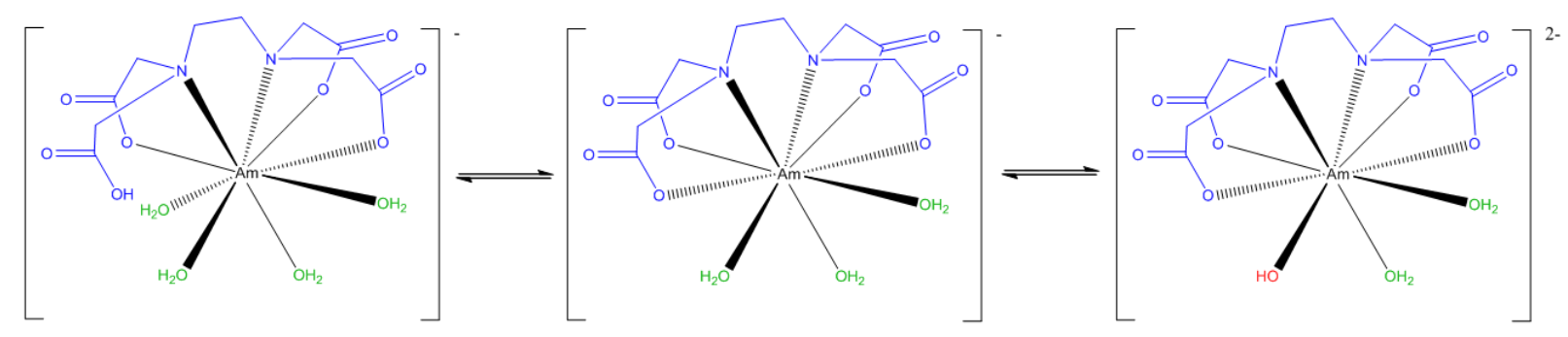

Figure 11. Possible structures of; A) $\left[\operatorname{Am}(\operatorname{HEDTA})\left(\mathrm{H}_{2} \mathrm{O}\right)_{4}\right]_{(\mathrm{aq})}$; B) $\left[\mathrm{Am}(\operatorname{EDTA})\left(\mathrm{H}_{2} \mathrm{O}\right)_{3}\right]_{(\mathrm{aq})}^{-}$and C) $\left[\operatorname{Am}(\text { EDTA })(\mathrm{OH})\left(\mathrm{H}_{2} \mathrm{O}\right)_{2}\right]_{(\text {(аq) }}^{2-}$ species.

The differences between the speciation diagrams illustrated in Figures 9 and 10 is most likely due to the established $\log \beta_{[\mathrm{Am}(\mathrm{EDTA})]^{-}}$value of 16.4 (determined in $0.5 \mathrm{M} \mathrm{Na}^{+}$electrolyte at 
$25^{\circ} \mathrm{C}$ ) not being correct for the system that we have used in the luminescence studies (approx. $2 \mathrm{M} \mathrm{NaNO}_{3}$ at room temperature). A replot of the speciation diagram, keeping all other factors the same as Figure 10 but reducing the $\log \beta_{[\mathrm{Am}(\mathrm{EDTA})]^{-} \text {value from } 19.6 \text { (established value }}$ corrected to zero ionic strength) to 14 (hypothetical value), is shown in Figure 12. The reduced $\log \beta_{[\mathrm{Am}(\mathrm{EDTA})]^{-}}$value causes a relatively gradual increase in the concentration of the [Am(EDTA)] $_{\text {(aq) }}^{-}$species as $\mathrm{pH}$ is raised from 2.7 to 8 (compared to [Am(EDTA)] ${ }_{\text {(aq) }}^{-}$speciation in Figure 10), which gives a reasonable correlation with the speciation profile obtained from our luminescence experiments. Therefore, indicating the $\log \beta_{[\mathrm{Am}(\mathrm{EDTA})]^{-}}$value in $2 \mathrm{M} \mathrm{NaNO}_{3}$ is lower than what might be expected from previous studies. The predicted speciation profile shows a decrease in the concentration of the $[\mathrm{Am}(\mathrm{EDTA})]_{(\mathrm{aq})}^{-}$species above $\mathrm{pH} 8$ due to the formation of insoluble hydrolysis products. However, it is expected that a soluble hydrolysed species, $[\text { Am(EDTA)(OH) }]_{(\text {aq) }}^{2-}$, forms above pH 8, but has not been modelled in the speciation diagram. 


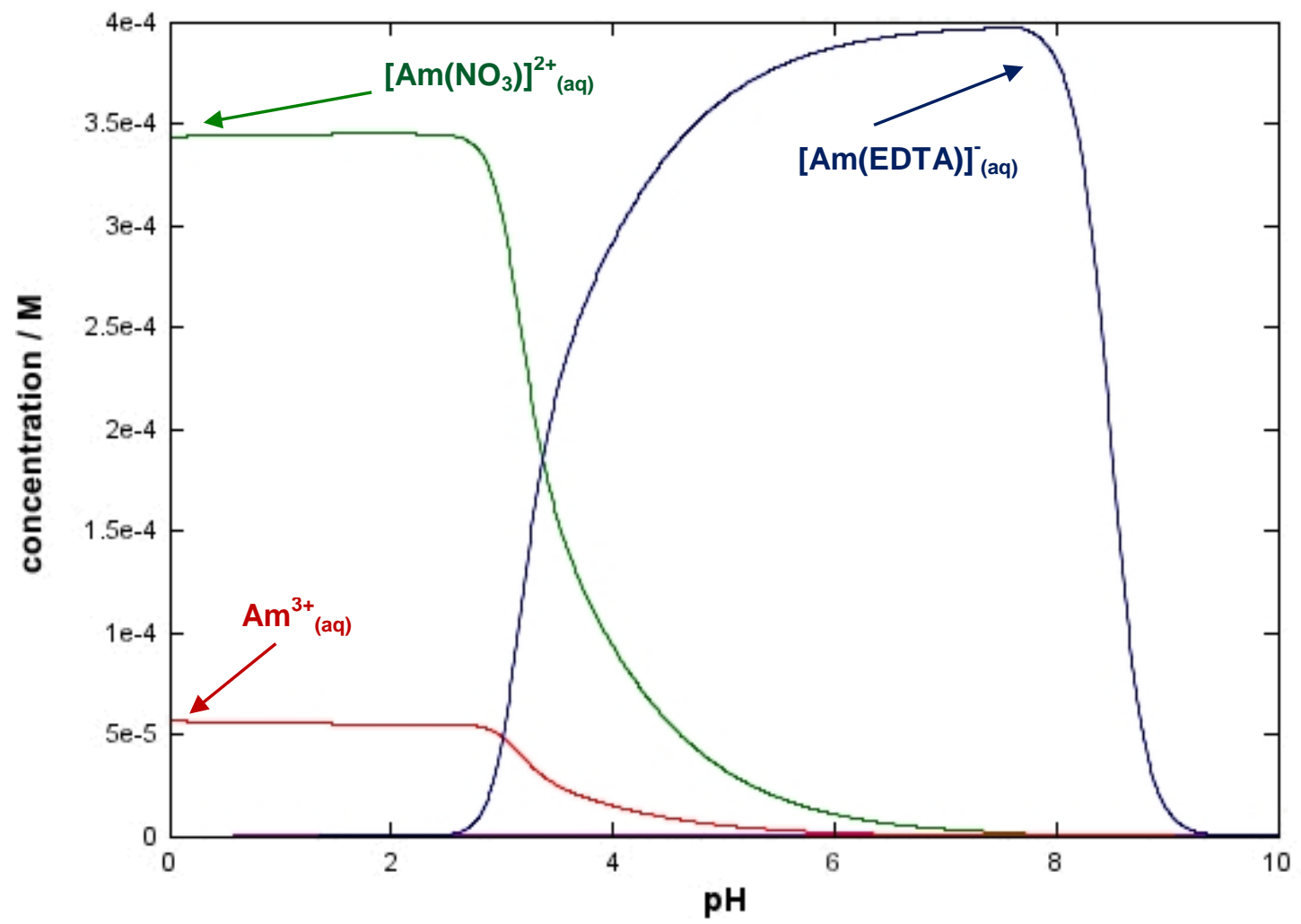

Figure 12. Speciation diagram of a $1: 1 \mathrm{Am}^{\mathrm{III}}: \mathrm{EDTA}^{4-}$ system as a function of $\mathrm{pH}$ using the JCHESS code with a reduced $\log \beta_{[\mathrm{Am}(\mathrm{EDTA})]^{-}}$value compared to Figure $10 .{ }^{31}$ Total $\left[\mathrm{Am}^{\mathrm{III}}\right]=$ total $\left.\left[\mathrm{EDTA}^{4-}\right]=4 \times 10^{-4} \mathrm{M} ; \mathrm{NO}_{3}\right]^{-}=2 \mathrm{M}$. Only soluble species are shown. Thermodynamic data obtained from the integrated JCHESS database, as well as Martell and Smith (corrected to zero ionic strength using the Davies Equation). ${ }^{12}$

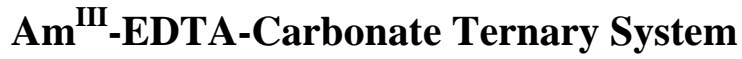

Luminescence spectroscopy performed on the $1: 1: 1 \mathrm{Am}^{\mathrm{III}}: \mathrm{EDTA}^{4-}: \mathrm{CO}_{3}{ }^{2-}$ system as a function of pH, adjusted using $\mathrm{NaOH}$, shows that the luminescence lifetime of the excited $\mathrm{Am}^{\mathrm{III}}$ species has increased in the presence of carbonate ions compared to when carbonate ions are absent in the system (see Suppl. Info.). It is likely that the carbonate anion is replacing inner-sphere water molecules in the $[\mathrm{Am}(\mathrm{EDTA})]_{(\mathrm{aq})}^{-}$complex, and so decreasing the number of $\mathrm{OH}$ oscillators that 
quench $A m^{\text {III }}$ luminescence. Overlaying the data for the $N_{\mathrm{H}_{2} \mathrm{O}}$ bound to the $\mathrm{Am}^{\mathrm{III}}$ ion in the $1: 1$ $A m^{\text {III }}:$EDTA$^{4-}$ and the $1: 1: 1 \mathrm{Am}^{\mathrm{III}}: \mathrm{EDTA}^{4-}: \mathrm{CO}_{3}{ }^{2-}$ systems shows a decrease in the $N_{\mathrm{H}_{2} \mathrm{O}}$ coordinated to the $[\text { Am(EDTA) }]_{\text {(aq) }}^{-}$complex from $\sim 3 / \sim 4$ to $\sim 2 / \sim 3$, over the $\mathrm{pH}$ range 8 to 11 (Figure 8). This is indicative of the carbonate anion either in dynamic exchange with water molecules for coordination to the $[\text { Am(EDTA) }]_{\text {(aq) }}^{-}$complex (Figure 13), and/or only a fraction of the $[\mathrm{Am}(\mathrm{EDTA})]^{-}{ }_{\text {(aq) }}$ complex is converted to the $\left[\mathrm{Am}(\mathrm{EDTA})\left(\mathrm{CO}_{3}\right)\right]^{3-}{ }_{(\mathrm{aq})}$ species under these solution conditions. Above $\mathrm{pH} 11$, the $N_{\mathrm{H}_{2} \mathrm{O}}$ coordinated to the [Am(EDTA)] ${ }_{\text {(aq) }}$ complex decreases to 1.4. This is likely to correlate to the formation of hydrolysed species (e.g. $[\mathrm{Am}(\mathrm{EDTA})(\mathrm{OH})]_{(\mathrm{aq})}^{2-}$ and/or $\left.\mathrm{Am}(\mathrm{OH})_{3(\mathrm{~s})}\right)$.
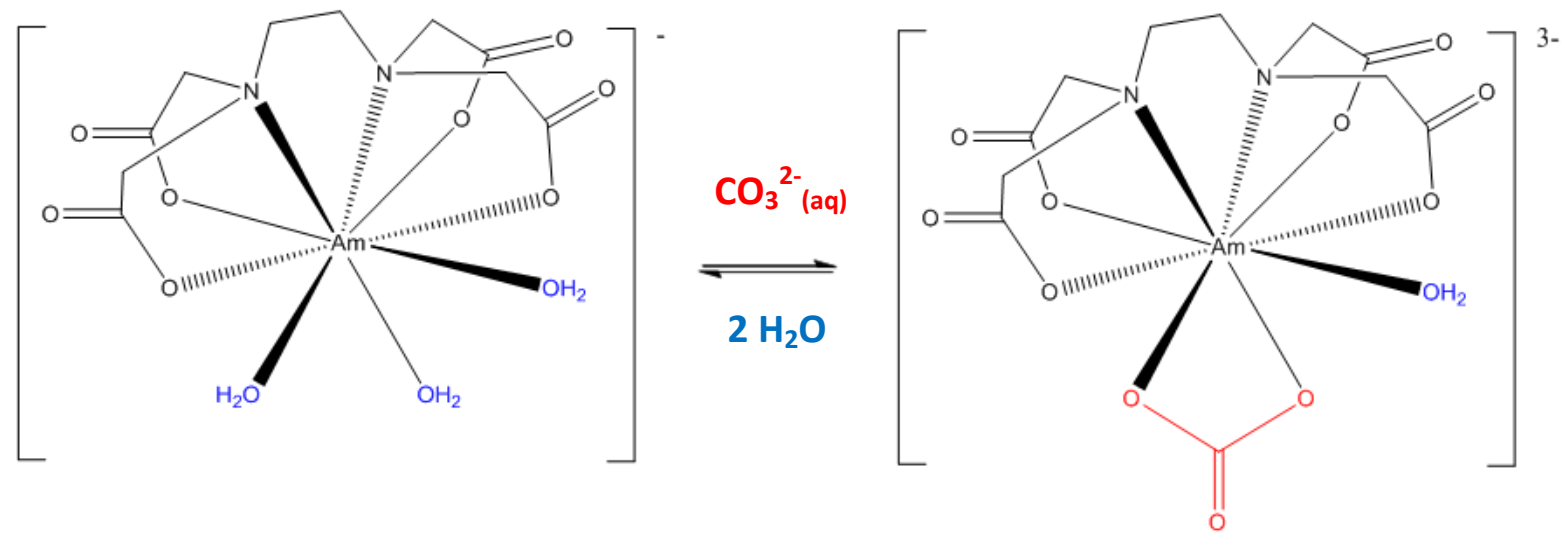

Figure 13. The exchange of $\mathrm{H}_{2} \mathrm{O}$ and $\mathrm{CO}_{3}{ }^{2-}$ (aq) for complexation to [Am(EDTA)] ${ }_{(\text {aq) }}^{-}$.

An excess of carbonate ions added to the 1:1 Am ${ }^{\text {III }}:$ EDTA $^{4-}$ system showed no significant difference in the luminescence lifetime of the $\left[\mathrm{Am}(\mathrm{EDTA})\left(\mathrm{CO}_{3}\right)\left(\mathrm{H}_{2} \mathrm{O}\right)\right]^{3-}{ }_{(\mathrm{aq})}$ species. Therefore, it is unlikely that two carbonate anions are coordinating to the [Am(EDTA) $]^{-}$(aq) complex. 


\section{Conclusions}

We have provided a deeper qualitative insight into the nature of minor actinide coordination chemistry in mixed-ligand environments over a wide $\mathrm{pH}$ range. The formation of An-organic and mixed $[\text { An(organic)(inorganic) }]_{(\text {aq })}^{n-}$ complexes $($ i.e. $\mathrm{An}=\mathrm{Am}$ or $\mathrm{Cm}$, organic $=\mathrm{EDTA}$, and inorganic $=\mathrm{OH}^{-}$or $\mathrm{CO}_{3}{ }^{2-}$ ) increase the solubility of minor actinide ions at high $\mathrm{pH}$.

In $\mathrm{An}^{\mathrm{III}}: \mathrm{EDTA}^{4-}: \mathrm{CO}_{3}{ }^{2-}$ ternary systems, the interaction of $\mathrm{CO}_{3}{ }^{2-}$ with [An(EDTA)] ${ }^{-}$(aq) complexes was predominantly observed over the $\mathrm{pH}$ range 8 to 11 . Use of luminescence spectroscopy to calculate the $N_{\mathrm{H}_{2} \mathrm{O}}$ bound to the $\mathrm{Am}^{\mathrm{III}}$ ion in the $1: 1 \mathrm{Am}^{\mathrm{III}}: \mathrm{EDTA}^{4-}$ and the 1:1:1 $\mathrm{Am}^{\mathrm{III}}: \mathrm{EDTA}^{4-}: \mathrm{CO}_{3}{ }^{2-}$ systems over the $\mathrm{pH}$ range 8 to 11 , showed a reduction in $N_{\mathrm{H}_{2} \mathrm{O}}$ in the ternary system compared to the binary system. This suggests that equilibria between binary and ternary species exist in solution.

In experiments where $\mathrm{An}^{\mathrm{III}}: \mathrm{EDTA}^{4-}: \mathrm{CO}_{3}{ }^{2-}$ ternary complexes were shown to exist, when the $\mathrm{pH}$ is greater than 10 , it is likely that hydroxide replaces the carbonate in preference to EDTA ${ }^{4-}$. This is due to the greater thermodynamic stability of the multidentate ligand.

At low $\mathrm{pH}$ values between 2 to 3 , the $[\mathrm{An}(\mathrm{EDTAH})]_{(\mathrm{aq})}$ species may be dominant in the systems studied $\left(c f .[\operatorname{La}(\mathrm{EDTAH})]_{(\mathrm{aq})}\right.$ species) ${ }^{12}$ However, there are no reported $\log \beta$ values for the formation of the $[\mathrm{An}(\mathrm{EDTAH})]_{(\mathrm{aq})}$ species.

It is envisaged that the determination of metal ion speciation using a combination of UV-Vis and luminescence spectroscopies could be applied to new characterisation challenges faced in the future of the nuclear industry. 


\section{Acknowledgements}

This work was supported by the Nuclear Decommissioning Authority U.K. (student bursary for TLG, research fellowship for CAS and the work at NNL), the University of Manchester Alumni Fund (TLG) and also the RCUK Energy Programme through its support of the MBase consortium. The work at INL was supported from the DOE NE FCR\&D Thermodynamics and Kinetics program, under DOE Idaho Operations Office Contract DE-AC07-05ID14517. We wish to acknowledge helpful discussions with Louise Natrajan on the luminescence work.

\section{References}

(1) Choppin, G. R.; Thakur, P.; Mathur, J. N. C. R. Chimie 2007, 10, 916-928.

(2) Hummel, W.; Puigdomènech, I.; Rao, L.; Tochiyama, O. C. R. Chimie 2007, 10, 948-958.

(3) Lambert, T. N.; Jarvinen, G. D.; Gopalan, A. S. Tetrahedron Lett. 1999, 40, 1613-1616.

(4) Wood, S. A. Eng. Geol. 1993, 34, 229-259.

(5) Pathak, P. N.; Choppin, G. R. Radiochim. Acta 2006, 94, 81-86.

(6) Warwick, P. E. Environmental Radiochemical Analysis II; Royal Society of Chemistry: UK, 2003.

(7) Schnitzer, M. Humic Substances in the Environment; Marcel Dekker Inc: New York, 1972.

(8) Yamamoto, Y.; Takahashi, Y.; and Shimizu, H. Chem. Lett. 2005, 34, 880-881.

(9) Riggle, J.; von Wandruszka, R. Annals of Environmental Science 2008, 2, 1-6

(10) Sakuragi, T.; Sawa, S.; Sato, S.; Kozaki, T.; Mitsugashira, T.; Hara, M.; Suzuki, Y. J. Radioanal. Nucl. Ch. 2004, 261, 309-314.

(11) Morgenstern, M.; Klenze, R.; Kim, J. I.; Radiochim. Acta 2000, 88, 7-16. 
(12) (a) Smith, R. M.; Martell, A. E. Critical Stability Constants, Volumes 1 and 4: Inorganic Complexes; Plenum Press: New York, 1976. (b) Cernochova, K.; Mathur, J. N.; Choppin, G. R. Radiochim. Acta 2005, 93, 733-739. (c) Smith, T. D. J. Inorg. Nucl. Chem. 1959, 11, 314-319.

(13) Mathur, J. N.; Thakur, P.; Dodge, C. J.; Francis, A. J.; Choppin, G. R. Inorg. Chem. 2006, 45, 8026-8035.

(14) Verma, S.; Saxena, M. C. Proc. Indian Acad. Sci. 1987, 99, 217-222.

(15) Thakur, P.; Pathak, P. N.; Gedris, T.; Choppin, G. R. J. Solution Chem. 2009, 38, 265-287.

(16) Mathur, J. N.; Cernochova, K.; Choppin, G. R. Inorg. Chim. Acta 2007, 360, 1785-1791.

(17) Boukhalfa, H.; Reilly, S. D.; Smith, W. H.; Neu, M. P. Inorg. Chem. 2004, 43, 5816-5823.

(18) Rai, D.; Moore, D. A.; Rosso, K. M.; Felmy, A. R.; Bolton Jr., H. J. Solution Chem. 2008, 37, 957-986.

(19) Runde, W. Los Alamos Science 2006, 26, 392-411.

(20) Vercouter, T.; Vitorge, P.; Trigoulet, N.; Giffaut, E.; Moulin, C. N. J. Chem. 2005, 29, 544553.

(21) Vercouter, T.; Vitorge, P.; Amekraz, B.; Giffaut, E.; Hubert, S.; Moulin, C. Inorg. Chem. 2005, 44, 5833-5843.

(22) Kimura, T.; Nagaishi, R.; Kato, Y.; Yoshida, Z. Radiochim. Acta. 2001, 89, 125-130.

(23) Clark D. L.; Hobart, D. E.; Neu, M. P. Chem. Rev. 1995, 95, 25-48.

(24) Carnall, W. T.; Fields, P. R. J. Am. Chem. Soc. 1959, 81, 4445-4449.

(25) Barkleit, A.; Geipel, G.; Acker, M.; Taut, S.; Bernhard, G. Spectrochim. Acta. A. 2011, 78, 549552.

(26) Yusov, A. B. J. Radioanal. Nucl. Ch. 1990, 143, 287-294. 
(27) Beitz, J. V. J. Alloy. Compd. 1994, 207/208, 41-50.

(28) Kimura, T.; Kato, Y. J. Alloy. Compd. 1998, 271-273, 867-871.

(29) Runde, W. H.; Schulz, W. W. The Chemistry of the Actinide and Trans-actinide Elements:

Chapter 8; Springer: The Netherlands, 2010.

(30) Matonic, J. H.; Scott, B. L.; Neu, M. P. Inorg. Chem. 2001, 40, 2638-2639.

(31) Van der Lee, J. A Users Guide to CHESS, Another Speciation and Surface Complexation Computer Code, École des Mi1nes de Paris, Fontainebleau, 1998.

\section{List of Figure Captions}

Figure 1. Structures of the EDTA, NTA, citrate, ODA, IDA and carbonate ligands.

Figure 2. UV-Vis absorption spectra for the effect of $\mathrm{pH}$ on a $1: 1 \mathrm{Am}^{\mathrm{III}}$ :EDTA ${ }^{4-}$ system; $\left[\mathrm{Am}^{\mathrm{III}}\right]_{\mathrm{i}}=\left[\mathrm{EDTA}^{4-}\right]_{\mathrm{i}}=5 \times 10^{-5} \mathrm{M} ; I_{o}=0.5 \mathrm{M} \mathrm{NaNO}_{3}$.

Figure 3. Adjusted UV-Vis absorption spectra for the effect of $\mathrm{pH}$ on a $1: 1 \mathrm{Cm}^{\mathrm{III}}: \mathrm{EDTA}^{4-}$ system; $\left[\mathrm{Cm}^{\mathrm{III}}\right]_{\mathrm{i}}=\left[\mathrm{EDTA}^{4-}\right]_{\mathrm{i}}=2 \times 10^{-5} \mathrm{M} ; \mathrm{I}_{o}=0.5 \mathrm{M} \mathrm{NaNO}_{3}$.

Figure 4. UV-Vis absorption spectra for a $1: 1: X \mathrm{Am}^{\mathrm{III}}: \mathrm{EDTA}^{4-}: \mathrm{CO}_{3}{ }^{2-}$ system (where $X=0$ to 2 equivalents); $\left[\mathrm{Am}^{\mathrm{III}}\right]_{\mathrm{i}}=\left[\mathrm{EDTA}^{4-}\right]_{\mathrm{i}}=\left[\mathrm{CO}_{3}{ }^{2-}\right]_{\mathrm{i}}=5 \times 10^{-5} \mathrm{M} ; \mathrm{pH}=10 \pm 0.5 ; I_{o}=0.5 \mathrm{M} \mathrm{NaNO}_{3}$.

Figure 5. Adjusted UV-Vis absorption spectra for a 1:1:X Cm${ }^{\mathrm{III}}: \mathrm{EDTA}^{4-}: \mathrm{CO}_{3}{ }^{2-}$ system (where $X=0$ to 2 equivalents); $\left[\mathrm{Cm}^{\mathrm{III}}\right]_{\mathrm{i}}=\left[\mathrm{EDTA}^{4-}\right]_{\mathrm{i}}=\left[\mathrm{CO}_{3}{ }^{2-}\right]_{\mathrm{i}}=2 \times 10^{-5} \mathrm{M} ; \mathrm{pH}=10 \pm 0.5 ; I_{o}=0.5 \mathrm{M}$ $\mathrm{NaNO}_{3}$.

Figure 6. UV-Vis absorption spectra for the effect of $\mathrm{pH}$ on a 1:1:2 $\mathrm{Am}^{\mathrm{III}}: \mathrm{EDTA}^{4-}: \mathrm{CO}_{3}{ }^{2-}$ system; $\left[\mathrm{Am}^{\mathrm{III}}\right]_{\mathrm{i}}=\left[\mathrm{EDTA}^{4-}\right]_{\mathrm{i}}=5 \times 10^{-5} \mathrm{M} ;\left[\mathrm{CO}_{3}{ }^{2-}\right]_{\mathrm{i}}=1 \times 10^{-4} \mathrm{M} ; I_{o}=0.5 \mathrm{M} \mathrm{NaNO}_{3}$. 
Figure 7. The time-resolved emission spectra of the $\mathrm{Am}^{\mathrm{III}}{ }_{(\mathrm{aq})}$ ion; $\left[\mathrm{Am}^{\mathrm{III}}\right]=4 \times 10^{-4} \mathrm{M} ; \mathrm{I}=0.02$ $\mathrm{MHNO}_{3}$.

Figure 8. The effect of $\mathrm{pH}$ on the $N_{\mathrm{H} 2 \mathrm{O}}$ bound to the Am ${ }^{\mathrm{III}}$ ion in the $1: 1 \mathrm{Am}^{\mathrm{III}}$ :EDTA ${ }^{4-}$ $\left(\left[\mathrm{Am}^{\mathrm{III}}\right]_{\mathrm{i}}=\left[\mathrm{EDTA}^{4-}\right]_{\mathrm{i}}=4 \times 10^{-4} \mathrm{M} ; \quad\right.$ in approx. $2 \mathrm{M}$ nitrate solution $)$ and 1:1:1 $\mathrm{Am}^{\mathrm{III}}: \mathrm{EDTA}^{4-}: \mathrm{CO}_{3}{ }^{2-}$ systems $\left(\left[\mathrm{Am}^{\mathrm{III}}\right]_{\mathrm{i}}=\left[\mathrm{EDTA}^{4-}\right]_{\mathrm{i}}=\left[\mathrm{CO}_{3}{ }^{2-}\right]_{\mathrm{i}}=4 \times 10^{-4} \mathrm{M}\right.$; in approx. $2 \mathrm{M}$ nitrate solution). Average percentage error bars have been included for all plots of $N_{\mathrm{H} 2 \mathrm{O}} v s$. $\mathrm{pH}$.

Figure 9. Plot of the percentage formation of the $\left[\mathrm{Am}(\mathrm{EDTA})\left(\mathrm{H}_{2} \mathrm{O}\right)_{3}\right]^{-}{ }_{(\text {aq })}$ species as a function of $\mathrm{pH}$.

Figure 10. Speciation diagram of a $1: 1 \mathrm{Am}^{\mathrm{III}}$ EDTA $^{4-}$ system as a function of $\mathrm{pH}$ using the JCHESS code. Total $\left[\mathrm{Am}^{\mathrm{III}}\right]=$ total $\left[\mathrm{EDTA}^{4-}\right]=4 \times 10^{-4} \mathrm{M} ;\left[\mathrm{NO}_{3}\right]^{-}=2 \mathrm{M}$. Only soluble species are shown. Thermodynamic data obtained from the integrated JCHESS database, as well as Martell and Smith (corrected to zero ionic strength using the Davies Equation).

Figure 11. Possible structures of; A) $\left[\operatorname{Am}(\operatorname{HEDTA})\left(\mathrm{H}_{2} \mathrm{O}\right)_{4}\right]_{(\mathrm{aq})}$; B) $\left[\mathrm{Am}(\operatorname{EDTA})\left(\mathrm{H}_{2} \mathrm{O}\right)_{3}\right]_{(\mathrm{aq})}^{-}$and C) $\left[\mathrm{Am}(\mathrm{EDTA})(\mathrm{OH})\left(\mathrm{H}_{2} \mathrm{O}\right)_{2}\right]^{2-}{ }_{(\mathrm{aq})}$ species.

Figure 12. Speciation diagram of a $1: 1 \mathrm{Am}^{\mathrm{III}}$ EDTA $^{4-}$ system as a function of $\mathrm{pH}$ using the

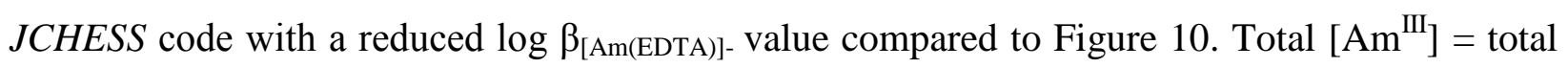
$\left[\mathrm{EDTA}^{4-}\right]=4 \times 10^{-4} \mathrm{M} ;\left[\mathrm{NO}_{3}\right]^{-}=2 \mathrm{M}$. Only soluble species are shown. Thermodynamic data obtained from the integrated JCHESS database, as well as Martell and Smith (corrected to zero ionic strength using the Davies Equation).

Figure 13. The exchange of $\mathrm{H}_{2} \mathrm{O}$ and $\mathrm{CO}_{3}{ }^{2-}{ }_{(a q)}$ for complexation to [Am(EDTA) ${ }^{-}{ }_{(\mathrm{aq})}$. 